\title{
The MANy Dimensions of SofTWOOD LUMBER
}

\author{
JEFFREY L. DUNOFF*
}

The Softwood Lumber dispute between Canada and the United States is one of the longest and most expensive trade disputes in history. However, the Softwood Lumber dispute has been, if not misunderstood, at least underappreciated. To date, the dispute has attracted attention because of the substantial economic interests involved, the complexity and length of the litigation, and the doctrinal implications of the various decisions rendered in domestic and international proceedings. This paper seeks to demonstrate that Softwood Lumber's central importance lies elsewhere; for trade scholars, Softwood Lumber is of interest because it exposes three of the central challenges facing the international trade regime: the potential displacement of an international regime by a spaghetti bowl of regional and bilateral treaties; the status of international trade norms in domestic courts; and the problem of selective and halting compliance by powerful states. But these challenges are, in turn, instantiations of three central challenges facing the field of public international law, namely the fragmentation of international law; the relationships among proliferating transnational courts; and the limits of (international) legalization. Thus, the systemic issues raised by Softwood Lumber provide a tour d'horizon of debates central to contemporary international trade law and public international law.
Le différend sur le bois d'œuvre entre le Canada et les États-Unis est l'un des conflits du genre le plus long et le plus onéreux de l'histoire. Cependant, ce conflit a été sous-apprécié, sinon incompris. Àce jour, le conflit a attiré de l'attention en raison des importants intérêts économiques impliqués, de la complexité et de la durée des poursuites et des implications de doctrine des diverses décisions rendues dans les poursuites intérieures et internationales. Cet article cherche à démontrer que l'importance centrale du bois d'œuvre est ailleurs; pour les érudits du commerce, le bois d'œuvre est important parce qu'il expose trois problèmes centraux auquel le commerce international fait face, notamment le déplacement éventuel d'un régime international par un ensemble de traités régionaux et bilatéraux, l'état des normes de commerce international dans les tribunaux intérieurs et le problème de la conformité sélective et arrêtée par des États puissants. Or, ces problèmes, sont en revanche, des instanciations de trois problèmes centraux auxquels le domaine du droit international public fait face, à savoir, la fragmentation du droit international, la relation entre la prolifération de tribunaux transnationaux et les limites de la légalisation (internationale). Ainsi, les problèmes systémiques découlant du bois d'œuvre donnent un tour d'horizon des débats se trouvant au centre du droit international contemporain et du droit international public.

\section{TABLE OF CONTENTS}

I. INTRODUCTION . . . . . . . . . . . . . . . . . . . . . . . . . . 320

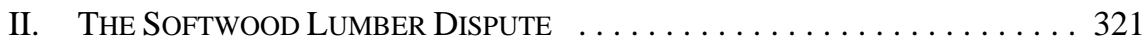

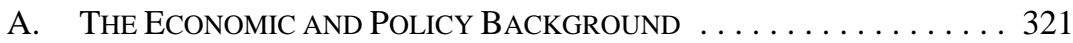

B. The Softwood Lumber LitigAtion . . . . . . . . . . . . . . 322

III. Challenges to the Trade System $\ldots \ldots \ldots \ldots \ldots \ldots \ldots \ldots \ldots \ldots$

A. The InCREASINGLy PROBLEMATIC RELATIONSHIP

BetweEn Multilateral AND PREFERENTIAL

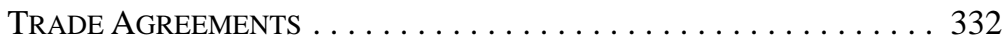

Visiting Senior Research Scholar, Law and Public Affairs Program and Visiting Professor, Woodrow Wilson School, Princeton University; Charles Klein Professor of Law \& Government and Director, Institute for International Law \& Public Policy, Temple University Beasley School of Law. This article is a revised version of a presentation at the Symposium entitled "Free Trade or Fair? The Softwood Lumber Dispute and Beyond” in March 2007. I am grateful to Symposium organizers Russell A. Miller and Rebecca M. Bratspies for the opportunity to participate in this Symposium, and to Symposium participants for their useful comments. 


\section{B. The Relationship AMONG Multiple \\ DisPUTE RESOLUTION FORA $\ldots \ldots \ldots \ldots \ldots$. . . . . . . . 337}

C. The Challenge Of SElective AND

HALTING COMPLIANCE . . . . . . . . . . . . . . . 343

IV. Challenges to THE InTERnATIONAL SYSTEM . . . . . . . . . . . . . . 349

A. The Fragmentation of InTERnATIONAL LAW . . . . . . . . . . . 350

B. The Challenges Posed By Multiple

INTERNATIONAL TRIBUNALS $\ldots \ldots \ldots \ldots \ldots \ldots \ldots \ldots \ldots \ldots \ldots$

C. The LiMits of LEgALIZATION . . . . . . . . . . . . . . . . . . . . . 353

V. FAIR TRADE: THE RELATIONS AMONG DiVERSE

INTERNATIONAL LEGAL REGIMES $\ldots \ldots \ldots \ldots \ldots \ldots \ldots \ldots \ldots$

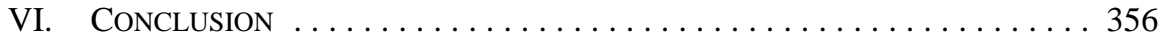

\section{INTRODUCTION}

In domestic law, certain cases represent an era. In the United States, cases like Lochner v. New York, ${ }^{1}$ Brown v. Board of Education, ${ }^{2}$ and Roe v. Wade, ${ }^{3}$ are canonical not only because they address foundational issues, but also because they serve as reference points for legal thought at a particular point in time. Decisions in canonical cases like these frequently capture forms of argumentation, professional preoccupations, or approaches to legal problems that characterize an era. ${ }^{4}$ So too in the Canadian legal system. Cases like Labour Conventions, ${ }^{5}$ R. v. Oakes, ${ }^{6}$ and Halpern v. Canada, ${ }^{7}$ are canonical because of the issues addressed, the arguments employed, and the conclusions reached.

Much the same is true in international law. Decisions like The Case of the S.S. "Lotus"8 and Ex parte Pinochet Ugarte (No.3) ${ }^{9}$ stand for an era, a mode of thought, as well as a set of institutional and doctrinal issues. Is the Softwood Lumber dispute canonical in this sense? Although it is surely much too soon to know, my sense is that because this dispute involves extremely arcane points of anti-dumping and countervailing duty law and an extraordinarily convoluted litigation history, it is unlikely to enter the trade law canon. Nevertheless, the Softwood Lumber dispute reveals much about the professional preoccupations, puzzles, and perplexities that mark the current era of international trade law, and public international law more generally. Hence, this essay focuses less on the finer points of trade law associated with the dispute than on the systemic issues that this rich and complex dispute raises. In short, this article seeks to illuminate some the many dimensions of the Softwood Lumber dispute.

198 U.S. 45 (1905).

347 U.S. 483 (1954).

410 U.S. 113 (1973).

For more on legal canons, see J.M. Balkin \& Sanford Levinson, “The Canons of Constitutional Law,” Commentary, (1998) 111 Harv. L. Rev. 963; Judith Resnik, “Constructing the Canon” (1990) 2 Yale J.L. \& Human. 221.

Canada (A.G.) v. Ontario (A.G.); Reference Re Weekly Rest in Industrial Undertakings Act, Minimum Wages Act and Limitation of Hours of Work Act, [1937] A.C. 326 (P.C.), aff'g [1936] S.C.R. 461.

[1986] 1 S.C.R. 103.

Halpern v. Canada (A.G.) (2003), 65 O.R. (3d) 161 (C.A.).

(1927), P.C.I.J. (Ser. A.) No. 10.

[2000] 1 A.C. 147 (H.L.). 
To do so, this article proceeds as follows. Part II provides a brief background to the longstanding differences between Canada and the U.S. over the harvesting of timber and international sale of softwood lumber, as well as a quick overview of the recent litigation arising out of these differences. Part III argues that the Softwood Lumber dispute can be understood as a lens into three of the central dilemmas now facing the trade system, namely (i) the changing relationship between proliferating numbers of preferential trade agreements and the multilateral trade system; (ii) the problematic relationships among domestic and international tribunals and dispute resolution fora; and (iii) selective and halting compliance by powerful states. Part IV argues that these three challenges are not unique to trade; rather the challenges confronting the trade system are instantiations of three of the most difficult issues facing public international law, namely (i) the fragmentation of international law; (ii) the relationships among proliferating international tribunals; and (iii) the limits to the legalization of international relations. Part V argues that the Softwood Lumber dispute points towards a rather unconventional understanding of the relationship between international trade law and other areas of international law.

Of course, each of the challenges identified above has spawned a large body of scholarship, and this article can do no more than outline many of the arguments raised in this literature. Nevertheless, I hope that the arguments presented in this article can serve as a bridge between the Symposium contributions that focus on the relationship between trade law and public international law, and those that focus on the relationship between international trade law and state sovereignty. More importantly, I intend for this article to demonstrate that the systemic issues raised by the Softwood Lumber dispute provide a tour d'horizon of debates central to contemporary international trade law and public international law.

\section{THE SOFTWOOD LUMBER DISPUTE}

The export of Canadian softwood lumber to the U.S. has long sparked controversy. In the 1820s, for example, New Brunswick and Maine clashed over exports of Canadian softwood lumber. Lumber also figured prominently in debates over a Canada-U.S. reciprocity treaty during the 1850s, as well as in later disagreements throughout the late $1800 \mathrm{~s}$ and $1900 \mathrm{~s} .{ }^{10}$ For present purposes, however, it is sufficient to review only the last two decades of legal contestation. Before doing so, I provide a brief explanation of the economics and regulatory approaches that give rise to the softwood lumber dispute, as well as an overview of recent Softwood Lumber litigation.

\section{A. The Economic And Policy Background}

For many years, U.S. producers have not produced sufficient lumber to meet domestic demand. As a result, the U.S. has long imported softwood lumber, in particular from Canada. Trade in softwood lumber is extremely important to both countries. From the U.S. perspective, Canadian imports now supply more than one-third of the U.S. softwood lumber

10 For more on this history, see George Woodward Hotchkiss, History of the Lumber and Forest Industry of the Northwest (Chicago: G.W. Hotchkiss \& Co., 1898); Russell Uhler, Canada-United States Trade in Forest Products (Vancouver: University of British Columbia Press, 1991). 
market, and the housing and other industries have come to depend upon access to this product. ${ }^{11}$ From the Canadian perspective, softwood lumber represents one of Canada's largest exports to the U.S.; in 2005, for example, 21.5 billion board feet of lumber, worth CDN\$8.5 billion, were shipped from Canada to the U.S. ${ }^{12}$

However, sharp differences regarding this trade have arisen, in part, because of significant differences between Canadian and U.S. methods of forest ownership and management. In the U.S., roughly 70 percent of forest land is privately owned, and approximately 90 percent of lumber is produced from timber harvested on privately owned lands. ${ }^{13}$ As a general matter, firms compete for the right to harvest timber in the U.S. through auctions; the price firms pay to harvest timber is thus determined by a market mechanism.

In Canada, by contrast, approximately 94 percent of forests are owned by either federal or provincial governments (so-called “Crown land”). ${ }^{14}$ Harvests on Crown lands are heavily regulated, and limited by annual allowable cuts. Canadian government officials set the price for harvesting the timber on public lands, called the "stumpage fee." These fees are set administratively, rather than through a market mechanism. Moreover, governments typically consider non-market-based criteria when setting these fees, including provincial revenue goals and the potential jobs created by harvesting operations. ${ }^{15}$

As a general matter, the Softwood Lumber disputes have centered upon the level of these stumpage fees. Many in the U.S. claim that Canadian officials set stumpage fees at well below market rates. As a result, U.S. interests argue that Canadian softwood lumber is unfairly subsidized, and that this product is being dumped into the U.S. market. ${ }^{16}$

\section{B. THE SOFTWOOD LUMBER LITIGATION}

U.S. trade law addresses imports that receive foreign government subsidies, as well as imports that are sold in the U.S. at less than fair market value. In particular, U.S. law authorizes the imposition of special duties, called countervailing duties, on goods that have been unfairly subsidized by foreign governments. Under U.S. law, countervailing duties may be imposed if (i) the Department of Commerce (DOC) finds that a foreign government is providing a subsidy with respect to the manufacture, production, or export of goods imported into the U.S., and (ii) the International Trade Commission (ITC or Commission) determines that a U.S. industry is materially injured, or threatened with material injury, by reason of

11 For a highly detailed economic analysis of this trade, see Softwood Lumber from Canada, Inv. Nos. 701TA-414, 731-TA-928, USITC Pub. 3509 (May 2002).

12 Foreign Affairs and International Trade Canada (FAITC), "Export and Import Controls — Softwood Lumber,” online: FAITC <http://www.dfait-maeci.gc.ca/eicb/softwood/intro-en.asp>.

13 David R. Boyd, Unnatural Law: Rethinking Canadian Environmental Law and Policy (Vancouver: University of British Columbia Press, 2003) at 130.

14 Ibid. The overwhelming majority of Crown lands — over 75 percent — is owned by provincial governments; the federal government owns only approximately 22 percent of Crown lands. Only 6 percent of Canada's forested land is privately owned. These lands are found primarily east of Manitoba, particularly in the Maritimes (Prince Edward Island, Nova Scotia, New Brunswick, and Newfoundland).

15 See e.g. Ross W. Gorte \& Jeanne J Grimmett, Lumber Imports From Canada: Issues and Events (Washington, D.C.: Congressional Research Service; Library of Congress, 2001) (recounting allegations of U.S. lumber industry with respect to non-market motivations for level of stumpage fees). Ibid. 
imports of these goods. Under these circumstances, a countervailing duty may be imposed in an amount equal to the amount of the government subsidy. ${ }^{17}$

U.S. anti-dumping law applies to imported products sold in the U.S. at less than fair market value. In particular, U.S. law authorizes the imposition of special duties, called antidumping duties, if (i) the DOC finds that foreign merchandise is being, or is likely to be, sold in the U.S. at less than fair value, and (ii) the ITC determines that an industry in the U.S. is materially injured, or threatened with material injury, as a result of the import of dumped products. Under these circumstances, an anti-dumping duty may be imposed in an amount equal to the amount by which the normal value exceeds the export price for the merchandise. $^{18}$

As explained in more detail below, much of the Softwood Lumber litigation involves the application of U.S. anti-dumping and countervailing duty laws. For current purposes, the relevant conduct started in 1986, when the U.S. Coalition for Fair Lumber Imports (Coalition), an alliance of U.S. sawmills, lumber workers, and woodland owners, filed a countervailing duty petition with the DOC. The petition alleged that the Canadian government was subsidizing certain softwood lumber products. The DOC made a preliminary determination that Canadian softwood lumber was being subsidized. A final determination was scheduled to be released on 30 December 1986. However, on that date, the U.S. and Canada entered into a Memorandum of Understanding (MOU). The MOU provided that the U.S. would terminate the countervailing duty investigation; Canada, in turn, agreed to impose a 15 percent export tax on Canadian softwood lumber products exported to the U.S. The MOU also provided that, in exchange for certain "replacement measures" requested by the U.S., the export tax could be gradually reduced. ${ }^{19}$ Over time, the requested replacement measures offset the alleged subsidy, and the export tax was eliminated for softwood lumber from British Columbia and reduced to 3.1 percent for softwood lumber from Quebec. ${ }^{20}$

The MOU provided that either party could terminate on 30 days notice; on 3 September 1991, Canada notified the U.S. that it would terminate the MOU effective 4 October $1991 .^{21}$ On the day the MOU terminated, the U.S. Trade Representative (USTR) self-initiated a s. 301 investigation, and immediately determined that Canada's termination of the MOU was unreasonable and would have the effect of burdening or restricting U.S. commerce. As a result, the U.S. immediately imposed bonding requirements on the import of Canadian softwood lumber. ${ }^{22} \mathrm{~A}$ few weeks later, the DOC initiated a countervailing duty investigation which ultimately led to the imposition of countervailing duties on softwood lumber from

See Countervailing and Antidumping Duties, Subtitle IV of the Tariff Act, 1930, 19 U.S.C. §1671. Ibid., 19 U.S.C. §1671-71(h), §1673-73(h), §1675-75(a), §1677-77(n).

Memorandum of Understanding, U.S. and Canada, 30 December 1986.

Runsheng Yin \& Jungho Baek, “The US-Canada softwood lumber trade dispute: what we know and what we need to know” (2004) 6 Forest Policy and Economics 129.

Supra note 19.

United States - Measures Affecting Imports of Softwood Lumber from Canada (1993), GATT Doc. SCM/162, online: WTO <http://docsonline,wto.org>. Canada successfully challenged these interim duties before a GATT panel. The panel found that the interim duties violated U.S. obligations under the 1979 Agreement on Interpretation and Application of Articles VI, XVI and XXIII of the General Agreement on Tariffs and Trade, 12 April 1979, 18 I.L.M. 553, online: World Trade Law <http:// www.worldtradelaw.net/tokyoround/subsidiescode.pdf $>$ [Subsidies Code]. 
Canada, except for lumber from the Maritimes. ${ }^{23}$ Canada challenged these duties under the Free Trade Agreement between the Government of Canada and the Government of the United States of America. ${ }^{24}$ After a flurry of litigation the U.S. revoked these duties in $1994 .{ }^{25}$

Negotiations during 1995 and 1996 ultimately led to the 29 May 1996 Softwood Lumber Agreement between the Government of Canada and the Government of the United States. ${ }^{26}$ This agreement provided that a specified volume of Canadian softwood lumber could enter the U.S. duty free; thereafter an export tax would be imposed on a sliding scale. The 1996 SLA brought a temporary truce in the legal skirmishes over softwood lumber. However, by its terms, the agreement expired on 31 March 2001; the following day, the Coalition filed petitions seeking the imposition of countervailing and anti-dumping duties. In 2001 and 2002, the relevant U.S. agencies determined that (i) Canadian stumpage policies constituted countervailable subsidies; (ii) Canadian softwood lumber firms were dumping their products in the U.S. market; and (iii) imported Canadian softwood lumber threatened U.S. industry with material injury. ${ }^{27}$ As a result, the DOC imposed significant anti-dumping duties and countervailing duties upon Canadian softwood lumber. ${ }^{28}$

In 2002, Canada and Canadian lumber interests sought review of the DOC's countervailing duty and anti-dumping determinations, as well as ITC's injury determination, before the c. 19 panels under the North American Free Trade Agreement Between the Government of Canada, the Government of Mexico and the Government of the United States. ${ }^{29}$ Chapter 19 of the NAFTA provides for a binational panel system that, in effect, replaces federal court review of agency determinations in anti-dumping and countervailing

Self-Initiation of Countervailing Duty Investigation: Certain Softwood Lumber Products From Canada, 56 Fed. Reg. 56055 (31 October 1991).

242 January 1988, Can. T.S. 1989 No. 3, 27 I.L.M. 293 (entered into force 1 January 1989) [CUSFTA].

25 For the revocation, see Certain Softwood Lumber Products from Canada: Notice of Panel Decision, Revocation of Countervailing Duty Order and Termination of Suspension of Liquidation, 59 Fed. Reg. 42029-30 (16 August 1994). The litigation includes e.g. Re Certain Softwood Products from Canada, USA-92-1904-1 (6 May 1993) (challenge to final CVD determination); Re Certain Softwood Lumber from Canada, USA-92-1904-02 (26 July 1993) (challenge to final injury determination); Re Certain Softwood Lumber Products from Canada, USA-92-1904-01 (17 December 1993) (challenge to remand determination); Re Certain Softwood Lumber Products from Canada, USA-92-1904-02 (28 January 1994) (challenge to ITC’s revised determination).

2629 May 1996, Can. T.S. 1996 No. 16, 35 I.L.M. 1197 (entered into force 1 April 1996) [1996 SLA].

$27 \quad$ Notice of Preliminary Affirmative Countervailing Duty Determination, Preliminary Affirmative Critical Circumstances Determination, and Alignment of Final Countervailing Duty Determination with Final Antidumping Duty Determination: Certain Softwood Lumber Products from Canada, 66 Fed. Reg. 43186 (17 August 2001); Notice of Preliminary Determination of Sales at Less Than Fair Value and Postponement of Final Determination: Certain Softwood Lumber from Canada, 66 Fed. Reg. 56062 (6 November 2001); Softwood Lumber from Canada, Inv. Nos. 701-TA-414 and 731-TA-928 (Final), USITC Pub. 3509 (May 2002).

28 Notice of Final Affirmative Countervailing Duty Determination and Final Negative Critical Circumstances Determination: Certain Softwood Lumber Products from Canada, 67 Fed. Reg. 15545 (2 April 2002); Notice of Amended Final Determination of Sales at Less Than Fair Value and Antidumping Duty Order: Certain Softwood Lumber Products from Canada, 67 Fed. Reg. 36068 (22 May 2002).

2917 December 1992, Can. T.S. 1994 No. 2, 32 I.L.M. 289 (entered into force 1 January 1994), c. 19, art. 1904 [NAFTA]. 
duty cases. ${ }^{30}$ Canada's challenges gave rise to numerous decisions by different binational panels. For example, the proceedings concerning countervailing duties gave rise to no less than five remands by binational panels to the DOC, and the proceedings challenging the finding that Canadian softwood lumber threatened material injury to a U.S. industry gave rise to three remands as well as proceedings before a NAFTA Extraordinary Challenge Committee (ECC). Some of these proceedings are discussed in more detail in Part III of this article; a figure outlining the relevant NAFTA c. 19 litigation can be found on pages 326-27.

In addition, at roughly the same time, Canada challenged the U.S.'s treatment of softwood lumber in a number of dispute resolution proceedings at the World Trade Organization (WTO). Specifically, Canada filed challenges to U.S. determinations regarding anti-dumping duties, countervailing duties, and threat of material injury. Some of the WTO proceedings are discussed in more detail in Part II of this article; a figure detailing the relevant WTO disputes can be found on page 328 .

As if these parallel litigation tracks were insufficiently complex, three Canadian lumber firms that had investments in the U.S. initiated proceedings against the U.S. pursuant to NAFTA c. 11. This chapter permits investors from one NAFTA party to commence international arbitration against another NAFTA party if it has suffered injury as a result of a breach of certain NAFTA provisions. Invoking this chapter, the firms - Canfor, Tembec, and Terminal — filed actions against the U.S. The firms alleged that the U.S.'s countervailing duties and anti-dumping measures were discriminatory, a denial of justice, and constituted indirect expropriations, all in breach of c. 11. The firms sought damages of not less than CDN\$540 million. After extensive litigation over procedural matters, the three cases were consolidated. A figure representing the relevant NAFTA c. 11 litigation can be found on page 329.

30 In general, agency determinations in anti-dumping and subsidy cases are subject to review by the U.S. Court of International Trade. This review, in turn, may be appealed to the U.S. Court of Appeals for the Federal Circuit. However, NAFTA c. 19 provides for a review by a binational panel of anti-dumping and countervailing duty determinations issued by national authorities. The binational panel system “replace[s] judicial review of final antidumping and countervailing duty determinations" (art. 1904(1)). The role of the panel is "to determine whether such determination was in accordance with the antidumping or countervailing duty law of the importing Party” (art. 1904(2)). Panels may either uphold a final determination or remand it for action not inconsistent with the panel's decision: art. 1904(8). A panel decision cannot be appealed to the domestic courts: art. 1904(11). An involved Party may avail itself of an extraordinary challenge procedure against a panel decision. However, only limited grounds are available, such as allegations that a panel member was guilty of gross misconduct or a serious conflict of interest: art. 1904(13). See also NAFTA, annex 1904.13 (setting out extraordinary challenge procedure). 
strip in file: page 326.pdf (located on disk in Dunoff Charts folder) 
strip in file: page 327.pdf (located on disk in Dunoff Charts folder) 
strip in file: page 328.pdf (located on disk in Dunoff Charts folder) 
strip in file: page 329.pdf (located on disk in Dunoff Charts folder) 
Finally, a flurry of law suits involving issues peripheral to the Softwood Lumber's central legal disputes were filed in U.S. courts. ${ }^{31}$ Although it is useful, for some purposes, to separate out these various litigation tracks and treat them as independent, the political reality is that these various tracks were components in a larger political and economic dispute involving numerous U.S. and Canadian interests. Hence, it is also useful to present a bird's eye view of the various Softwood Lumber dispute proceeding. A figure that details the various Softwood Lumber proceedings can be found on page 331.

See e.g. Baker \& Hostetler LLP v. Department of Commerce, 473 F.3d 312 (D.C. Cir. 2006) (action under the Freedom of Information Act, 5 U.S.C.S. § 55(b) (4), (5) to compel production of third-party letters and internal documents related to softwood lumber proceedings); Coalition for Fair Lumber Imports v. United States, 471 F.3d 1329 (D.C. Cir. 2006) (challenge to constitutionality of binational panel process dismissed for lack of jurisdiction); Forest Products Northwest v. United States, 453 F.3d 1355 (Fed. Cir. 2006) (unsuccessful suit by importer of Canadian forest products for refund of countervailing duty payments); Tembec, Inc. v. United States, 461 F.Supp. 2d 1355 (Ct. Int'l Trade 2006) (suit for refund of cash deposits made upon importation of softwood lumber), vacated by Tembec, Inc. v. United States, 475 F.Supp. 2d 1393 (Ct. Int'l Trade 2007), appeal dismissed, Tembec, Inc. v. United States, 2007 WL 1799686 (Fed. Cir. 2007); Tembec, Inc. v. United States (2006), 441 F.Supp. 1302 (Ct. Int'l Trade) (Uruguay Round Agreements Act [URAA] did not grant USTR authority to order the implementation of a s. 129(a) determination that does not result in at least partial revocation of an ant-dumping, countervailing duty or safeguards order); American Coalition for Competitive Trade $v$. Clinton, 128 F.3d 761 (D.C. Cir. 1997) (suit challenging constitutionality of binational panels dismissed for lack of standing); Tembec, Inc. v. United States, WL 1169346 (D.D.C. 2007) (unsuccessful effort to reopen action terminated by the 1996 SLA); Ontario Forest Industries Assoc. v. United States, 444 F.Supp. 2d 1309 (Ct. Int'l Trade 2006) (unsuccessful suit seeking writ of mandamus to compel USTR to appoint a member of a binational review panel to resolve a challenge to the legality of a final countervailing duty determination); Abitibi-Consolidated, Inc. v. United States, 437 F.Supp. 2d 1352 (Ct. Int'l Trade 2006) (unsuccessful suit by Canadian exporters of softwood lumber challenging DOC's respondent selection determinations in an administrative review of anti-dumping duties on softwood lumber); Canadian Lumber Trade Alliance v. United States, 425 F.Supp. 2d 1321 (Ct. Int'l Trade 2006) (successful challenge by Canadian producers to Custom's implementation of the Continued Dumping and Subsidy Offset Act of 2000, Pub. L. 106-387, Title X, §1002, 114 Stat. 1549 at 1549A-72 (2000) (codified as amended at 19 U.S.C. \$1675c (2000)), repealed by Pub. L. 109-171, Title VII, Subtitle F, $\S 7601(\mathrm{a}), 120$ Stat. 154 (2006) [Byrd Amendment], which is found to violate the NAFTA Implementation Act, 19 U.S.C.S. $\S 3438$ with respect to anti-dumping and countervailing duties on Canadian goods); Rivendell Forest Products v. Canadian Forest Products, 819 F.Supp. 1116 (D. Colo. 1993) (antitrust action against Canadian softwood lumber producers dismissed, in part, because the economic activity at issue is also subject to ongoing dispute between Canada and U.S.); MacMillan Bloedel v. United States, 16 C.I.T. 331 (Ct. Int'l Trade 1992) (unsuccessful suit to exclude Canadian firm from DOC's countervailing duty determination); Former Employees of Boise Cascade v. United States Secretary of Labor, 15 C.I.T. 116 (Ct. Int'l Trade 1991) (unsuccessful effort by former employees of U.S.-based softwood lumber firm to obtain trade adjustment assistance because their unemployment was caused by increased imports of softwood lumber products). 
strip in file: page 331.pdf (located on disk in Dunoff Charts folder) 
Canada and Canadian parties were successful in many — but no means all — of these legal proceedings. One result was a gradual, albeit partial, reduction in the composite antidumping and countervailing duty rate paid upon the importation of softwood lumber from Canada. ${ }^{32}$ In addition, the litigation helped produce a negotiated settlement. On 12 September 2006, the U.S. and Canada reached a framework agreement for resolving the softwood lumber controversy, which entered into force as amended on 12 October $2006 .{ }^{33}$ The agreement provides the revocation of countervailing and anti-dumping duties against Canadian softwood lumber, and the return of over $\$ 4.4$ billion in duties collected by the U.S. since 2002. In return, Canada agreed to maintain export measures on Canadian exports of softwood lumber to the United States. Canadian exports are unrestricted when lumber prices are above a specified price. If prices fall, each Canadian exporting region can choose to be subject to an export tax, or a lower tax and a quota. The agreement also includes a dispute settlement mechanism, should concerns arise regarding either party's implementation. The agreement is to run for a term of seven years, with the possibility of a two-year renewal.

\section{Challenges to The Trade System}

The highly compressed summary presented above reveals why the Softwood Lumber dispute is widely considered to be one of the lengthiest and most complex trade disputes to date. However, for present purposes, the dispute is more interesting for what it reveals about contemporary challenges to the trade system. I demonstrate below how the Softwood Lumber dispute helps to illuminate three of the central challenges currently facing the trade regime, namely (i) the rise and changing roles of preferential trade agreements within the context of a multilateral system; (ii) the complex relationships among domestic and international tribunals; and (iii) selective compliance by powerful states.

\section{A. The Increasingly Problematic Relationship Between Multilateral and Preferential Trade Agreements}

One of the most striking dimensions of the Softwood Lumber dispute is the complex relationship between the NAFTA and the WTO regimes. Although both the WTO and the NAFTA are, broadly speaking, trade liberalization agreements, their scope and provisions differ in important respects. Moreover, neither the WTO treaties nor the NAFTA addresses in detail the relationships, if any, among rules found in, or dispute settlement reports issuing from, the two systems.

In the Softwood Lumber dispute, questions regarding the interplay of regional and multilateral trade systems were particularly acute as, in at least some instances, NAFTA and WTO rules produced divergent panel rulings on similar issues. For example, as described in more detail below, after much litigation, a NAFTA c. 19 binational panel ordered the ITC to issue a negative threat of injury determination. The ITC did so, albeit reluctantly, and the negative injury finding was thereafter affirmed by the NAFTA panel. Thus, it would seem,

32 For an excellent discussion of these litigations and their results, see Chi Charmody, "Softwood Lumber Dispute (2001-2006)” (2006) 100 Am. J. Int’l L. 664.

33 Softwood Lumber Agreement between the Government of Canada and the Government of the United States of America, 12 September 2006, online: FAITC < http://www.international.gc.ca/eicb/softwood/ SLA-main-en.asp> (as am., entered into force 12 October 2006) [2006 SLA]. 
the NAFTA litigation resulted in a conclusive determination that Canadian softwood lumber imports neither caused nor threatened to cause material injury to U.S. industry. As a matter of U.S. law, absent injury, there is no basis for the imposition of anti-dumping or countervailing duties.

However, the ITC's injury determinations were also subject to a separate WTO proceeding. A WTO panel concluded that the ITC's finding of threat of injury violated the U.S.'s WTO obligations. ${ }^{34}$ Thereafter, the U.S. undertook a new investigation, and issued a redetermination of threat of injury. A subsequent WTO compliance panel upheld this determination. ${ }^{35}$ Thus, although the U.S. had issued a negative threat of injury determination as a result of the NAFTA litigation, after the WTO panel upheld a finding of injury, the USTR ordered the DOC to continue to collect duties on Canadian softwood lumber. ${ }^{36}$

The complex interplay — and potential inconsistencies — between the NAFTA and the WTO systems present in the Softwood Lumber dispute is a particular instance of a larger challenge facing the contemporary trade system, namely the changing and increasingly conflictual relationship between the multilateral system and regional or preferential trade agreements (PTAs).$^{37}$ To be sure, the tensions between regional and global trade treaties are not new. Indeed, from its inception, the multilateral system was designed to exist in tandem with PTAs, ${ }^{38}$ and economists almost immediately began debating whether regional trade agreements were trade-creating or trade-diverting, ${ }^{39}$ sparking a literature that continues to this

United States - Investigation of the International Trade Commission in Softwood Lumber from Canada (2004), WTO Doc. WT/DS277/R (Panel Report), online: WTO <http://docsonline.wto.org/gen_ search/asp>.

35 United States - Investigation of the International Trade Commission in Softwood Lumber from Canada - Recourse to Article 21.5 of the DSU by Canada (2005), WTO Doc. WT/DS277/RW (Panel Report), online:WTO <http://docsonline.wto.org/gen_search/asp>. Canada appealed the art. 21.5 panel decision to the Appellate Body and the Appellate Body reversed the decision: United States Investigation of the International Trade Commission in Softwood Lumber from Canada - Recourse to Article 21.5 of the DSU by Canada (2006), WTO Doc. WT/DS277/AB/RW (Appellate Body Report), online: WTO <http://docsonline.wto.org/gen_search/asp>. But the Appellate Body was unable to complete the analysis to determine whether the U.S. determination was consistent with the $A D$ and $C V D$ Agreements, noting that there was an absence of pertinent factual findings by the panel.

36 It bears noting that although the WTO and NAFTA findings are divergent, they are not necessarily inconsistent. The NAFTA panel sits, in effect, as a U.S. tribunal and applies U.S. domestic law. The WTO panel, in contrast, applies WTO law.

37 The terminology can be a bit tricky here. I wish to contrast the WTO agreements, on the one hand, and all bilateral, regional, and plurilateral trade agreements of a preferential nature, on the other hand. The traditional umbrella term for this latter group of agreements is "regional trade agreements." However, as described more fully in text, increasingly these agreements are entered into by states that are not geographical neighbours. Hence, I will usually refer to these agreements as PTAs rather than use the traditional term of regional trade agreements.

38 As an historic matter, most trade agreements that predated the General Agreement on Tariffs and Trade, 30 October 1947, 58 U.N.T.S. 187, Can. T.S. 1947 No. 27 (entered into force 1 January 1948) [GATT] contained an exception for PTAs: see e.g. U.N. Doc. EPCT/C.II/38 (1948) at 6 (stating that regional exception is a "standard clause in all commercial treaties") and the original GATT contained an exception for customs unions and free trade areas. For an interesting discussion of this history, see e.g. Thomas Cottier, “The Erosion of Non-Discrimination: Stern Warning without True Remedies” (2005) 8 J. Int'l Econ. L. 595.

39 This analysis is often traced to the writings of Jacob Viner. See e.g. Jacob Viner, The Customs Union Issue (New York: Carnegie Endowment for International Peace, 1950). 
day. ${ }^{40}$ An equally contentious, and equally longstanding, political economy literature addresses whether PTAs serve as building blocks or stumbling blocks to global trade liberalization efforts. ${ }^{41}$

But if the tension between global and regional initiatives is not new, what is new is the increasing density and scope of preferential agreements. Recent years have witnessed a frenzy of bilateral and regional trade agreements; indeed more PTAs were created during the WTO's first decade than during the GATT's five decades. For current purposes, however, the increasing number of these agreements does not fully capture what is at stake; in addition, several trends associated with the proliferation of new PTAs are cause for significant concern. $^{42}$

First, many states have moved the pursuit of PTAs to the center of their trade policy agendas. The U.S., for example, entered into PTA negotiations with eleven states and concluded three new PTAs in 2006 alone. ${ }^{43}$ The pursuit of increasing numbers of PTAs has absorbed enormous amounts of human resources and administrative capacity. As a World Bank study observed, “[r] eserves of administrative skill, political capital, or imagination are finite; if they are devoted to a [PTA] they are not available for multilateral objectives." ${ }^{44}$ Hence, in an important sense, the political and material resources devoted to the negotiation, ratification, implementation, and enforcement of PTAs has come at the expense of the multilateral system.

Second, although PTAs vary enormously in terms of their scope and depth, contemporary PTAs show increasing levels of sophistication. While some are limited to the exchange of tariff preferences on a narrow range of products, ${ }^{45}$ many other PTAs are highly comprehensive in coverage. The NAFTA is representative of the comprehensive PTAs, which often go beyond the WTO regulatory framework to include detailed provisions on investment, competition, intellectual property, environment, and labour among other topics.

For a survey of recent literature, see Arvind Panagariya, "Preferential Trade Liberalization: The Traditional Theory and New Developments” (2000) 38 Journal of Economic Literature 287. Other important contributions to this debate include Edward D. Mansfield \& Helen V. Milner, eds., The Political Economy of Regionalism (New York: Columbia University Press, 1997); Richard Pomfret, The Economics of Regional Trading Arrangements (Oxford: Oxford University Press, 2001); Jagdish Bhagwati, “Regionalism Versus Multilateralism” (1992) 15 The World Economy 535. Jagdish Bhagwati \& Anne O. Krueger, eds., The Dangerous Drift To Preferential Trade Agreements (Washington: The AEI Press, 1995) 1; compare with Richard E. Baldwin, "Multilateralising Regionalism: Spaghetti Bowls as Building Blocs on the Path to Global Free Trade” (2006) 29 The World Economy 1451.

42 The analysis that follows draws heavily upon Roberto V. Fiorentino, Luis Verdeja, \& Christelle Toqueboeuf, The Changing Landscape of Regional Trade Agreements: 2006 Update, WTO Discussion Paper, No. 12 (Geneva: World Trade Organization, 2007); Jo-Ann Crawford \& Roberto V. Fiorentino, The Changing Landscape of Regional Trade Agreements, WTO Discussion Paper, No. 8 (Geneva: World Trade Organization, 2005). Gabriela Carias-Green et al., “Business Regulation — International Trade” (2007) 41 Int’l Lawyer 229 at 231.

$44 \quad$ Trade Blocs, A World Bank Policy Research Report (New York: Oxford University Press, 2000) at 104; see also Colin B. Picker, "Regional Trade Agreements v. the WTO: A Proposal for Reform of Article XXIV to Counter this Institutional Threat” (2005) 26 U. Pa. J. Int'l Econ. L. 267 at 295.

45 PTAs between developing states that fall within the scope of the WTO's enabling clause tend to have limited product coverage. 
Notably, in recent years the regulation of issues beyond the WTO's ambit has been especially marked in PTAs among developed and developing economies. ${ }^{46}$ Thus, for example, the socalled "Singapore issues" of trade facilitation, investment, government procurement, and competition - which were rejected at the 2003 WTO Ministerial Conference in Cancun are being included in many recent PTAs, including those between developing and developed country partners. ${ }^{47}$

Third, PTAs were traditionally formed among so-called natural trading partners, often geographically contiguous countries with well-established trading patterns. The NAFTA is a paradigmatic example; the Australia-New Zealand Free Trade Agreement, ${ }^{48}$ the European Community (EC), and the Convention Establishing European Free Trade Association ${ }^{49}$ are other examples. To the extent that PTAs are driven by the search for access to larger markets, geographical proximity among PTA partners is not surprising, as the economies of scale associated with larger markets are frequently easier to achieve at the regional or bilateral level.

However, the rise of PTAs involving geographically diverse states suggests that political, rather than economic, considerations are increasingly a prime motivation for entering into PTAs. ${ }^{50}$ For example, the U.S. recently signed a free trade agreement with Oman. ${ }^{51}$ This agreement could hardly be expected to bring large economic benefits to the U.S. Rather, this agreement - like earlier agreements with other states in the area, including Israel, Jordan, Morocco, and Bahrain - is better understood as an effort to consolidate peace and increase regional security. In addition, it appears that states increasingly enter into PTAs to signal a commitment to good governance, or to lock-in political and economic reforms. ${ }^{52}$ PTAs may be used by larger states to forge new geopolitical alliances and to cement diplomatic ties, by providing increased access to a larger market. Finally, states sometimes enter into PTAs because they see other states doing so, and do not wish to be left behind, a phenomenon some call “domino regionalism." 53

See e.g. The World Bank, Global Economic Prospects 2005: Trade, Regionalism and Development (Washington, D.C.: The International Bank for Reconstruction and Development; The World Bank, 2005).

Examples of FTAs between developed and developing countries including all or some of the "Singapore issues” include: EC-South Africa, EFTA-Chile, U.S.-Morocco, U.S.-Jordan, and Thailand-Australia. FTA negotiations between EC-Mercosur and U.S.-Andean countries, among others, also contemplate the inclusion of these issues.

See online: New Zealand Ministry of Foreign Affairs \& Trade <http://www.mfat.govt.nz/Trade-andEconomic-Relations/Trade-Agreements/Asean/index.php>. 4 January 1960, 370 U.N.T.S. 3.

The distinction between market-driven and policy-driven regional integration is elaborated in Albert Fishlow \& Stephan Haggard, The United States and the Regionalisation of the World Economy (Paris: Organisation for the Economic Co-operation and Development, 1992).

$51 \quad$ See USTR, Press Release, “United States and Oman Sign Free Trade Agreement” (19 January 2006), online: USTR <http://ustr.gov/assets/Document_Library/Press_Releases/2006/January/asset_upload_ file25_8774.pdf>. The implementing legislation was signed into law in September 2006: U.S.-Oman Free Trade Agreement Implementation Act, Pub. L. No. 109-283, 120 Stat. 1191 (2006).

52 For example, many argue that the Salinas government joined the NAFTA, in part, to prevent future Mexican governments from reversing economic and political reforms: see e.g. Paul Krugman, "How Is NAFTA Doing?” The New Democrat 8 (May/June 1996) 18, online: The New Democrat <http:// www.ndol.org/documents/may96tnd.pdf >. 
The proliferation of PTAs holds several potentially negative consequences for the multilateral trade system. First, as a legal matter, the proliferation of PTAs seriously erodes the WTO's central non-discrimination norm. Although estimates vary, it appears that more than half of world trade today takes place under PTAs. Some have gone so far as to suggest that the WTO's "Most-Favoured-Nation" (MFN) clause ${ }^{54}$ is no longer the "central organizing rule of the ... world trading system" but instead is almost an "exception” that might be characterized as "Least-Favoured-Nation treatment." 55 For example, the European Union (EU) is party to so many PTAs and other preferential trade arrangements that its MFN tariffs are fully applicable to only nine of its trading partners. ${ }^{56}$

Moreover, as an economic matter, the proliferation of PTAs is unlikely to maximize aggregate global welfare. As noted above, economists have long debated whether the trade diversion effects of PTAs exceed their trade creation effects. Recent econometric evidence supports those who argue that PTAs enhance welfare less than multilateral liberalization. ${ }^{57}$ In particular, PTAs driven by political and security concerns are less likely to serve the economic interests of the parties, or the larger trading system. In addition, the recent flurry of "WTO plus" agreements, ${ }^{58}$ often between developed and developing states, are likely to impose economic costs on developing states. ${ }^{59}$

In addition, the proliferation of PTAs introduces a new set of costs. The multiplication of agreements means that multiple preferential tariff rates are being applied to multiple trading partners; rules of origin in these agreements are complex and inconsistent, and associated administrative and transaction costs are significant, particularly for small and medium sized firms and firms in developing states. ${ }^{60}$

Finally, as a political matter, ample grounds exist to conclude that ever-increasing numbers of PTAs constitute a stumbling block, rather than a building block, to global trade agreements. The Doha negotiations have demonstrated how states that enjoy preferential access to rich-country markets may be reluctant to support ambitious MFN tariff reductions

See Agreement Establishing the World Trade Organization, 15 April 1994, 1867 U.N.T.S. 154, 33 I.L.M. 1144 (entered into force 1 January 1995).

55 Peter Sutherland et al., The Future of the WTO: Addressing Institutional Challenges in the New Millennium, Report by the Consultative Board to the Director-General Supachai Panitchpakdi (Geneva: World Trade Organization, 2004) at 19 [The Future of the WTO]. The only WTO members to whom the EU does not provide preferential market access above and beyond its MFN commitments are Australia, Canada, Chinese Taipei, Hong Kong, China, Japan, Korea, New Zealand, Singapore, and the U.S.: ibid. at 21.

57 Glenn W. Harrison, Thomas F. Rutherford \& David G. Tarr, Rules of Thumb for Evaluating Preferential Trading Arrangements: Evidence from Computable General Equilibrium Assessments, Policy Research Working Paper, No. 3149 (Washington, D.C.: World Bank, Development Research Group, 2003), online: The World Bank <http://www-wds.worldbank.org/external/default/WDSContent Server/WDSP/IB/2003/12/15/0001600016_20031215112948/Rendered/PDF/wps3149.pdf>; Alexander J. Yeats, "Does Mercosur's trade performance raise concerns about the effects of regional trade arrangements?” (1998) 12 World Bank Econ. Rev. 1. See e.g. Julia Ya Qin, “'WTO Plus' Obligations and Their Implications for the World Trade Organization Legal System” (2003) 37 J. World Trade 483.

59 These costs are, perhaps, most pronounced in the intellectual property area. For a discussion, see Bryan Mercurio, “TRIPS-Plus Provisions in FTAs: Recent Trends" in Lorand Bartels \& Federico Ortino, eds., Regional Trade Agreements and the WTO Legal System (Oxford: Oxford University Press, 2006) 215. The Future of the WTO, supra note 55 at 22. 
that would erode the value of their preferences. The current negotiating impasse lends support to those who argue that the current "spaghetti bowl" of customs unions, common markets, and regional and bilateral free trade areas, raise the possibility that PTAs are now replacing, rather than complementing, the global trade system. ${ }^{61}$

In short, the proliferation of PTAs means that, for the first time since the dawning of the GATT era, the premise that international trade falls under one global regime based upon nondiscrimination is under very serious stress. Moreover, the apparent failure of the Doha Round raises the significant risk that all of these trends will only intensify. Given that the GATT/WTO system has been one of the most ambitious and successful elements of global economic governance, its potential displacement by a hodge-podge of PTAs represents a very serious systemic challenge.

\section{B. The Relationships Among Multiple Dispute Resolution Fora}

The Softwood Lumber dispute highlights a second set of challenges facing the multilateral trade system, namely the complications spawned by parallel litigation before multiple tribunals. To be sure, other trade disputes raise similar issues: the Bananas dispute generated multiple litigations before domestic, regional, and multilateral fora; ${ }^{62}$ the Argentina Poultry dispute involved successive litigations before Mercosur and the WTO; ${ }^{63}$ the Swordfish dispute was simultaneously before the WTO and UNCLOS systems; ${ }^{64}$ and Canada — Periodicals and Mexico - Softdrinks involved forum shopping between the NAFTA and WTO systems. ${ }^{65}$ But with three different lines of litigation proceeding virtually simultaneously before domestic fora, NAFTA panels, and WTO panels, the Softwood Lumber dispute presents in a particularly stark form the issues raised by litigation before multiple fora.

What should the relationship be between various domestic and supranational fora? For example, should NAFTA panels follow WTO holdings? Should WTO panels rely upon NAFTA panel determinations? What level of deference should international tribunals grant to domestic determinations? How should domestic tribunals treat international decisions? In the Softwood Lumber dispute, the relationships among various fora span a continuum from

$61 \quad$ Sungjoon Cho, “Defragmenting World Trade” (2006) 27 Nw. J. Int’l L. \& Bus. 39.

62 European Communities — Regime for the Importation, Sale and Distribution of Bananas (1997), WTO Doc. WT/DS27/AB/R (Appellate Body Report), online: WTO <http://docsonline.wto.org/gen_search/ asp>; Federal Republic of Germany v. Council of the European Union, C-290/93, [1994] E.C.R. I-4973; Firma T. Port v. Hauptzollamt Hamburg-Jonas, (T. Port II) FG Hamburg order (19 May 1995), [1995] EuZW 413, BFH decision (22 August 1995), T. Port II, Second banana ruling, BVerfG decisions of (26 April 1995), First Chamber of the Second Senate 2 BvR 760/95, [1995] EuZW 412.

63 Argentina-Definitive Anti-Dumping Duties on Poultry From Brazil (2003), WTO Doc. WT/DS241/R (Panel Report), online: WTO <http://docsonline.wto.org/gen_search/asp>.

64 Chile - Measures Affecting the Transit and Importation of Swordfish (Communication from the European Communites) (2001), WTO Doc. WT/DS193/3 (Arrangement between the European Communities and Chile), online: WTO <http://docsonline.wto.org/gen_search/asp>; Case Concerning the Conservation and Sustainable Exploitation of Swordfish Stocks in the South-Eastern Pacific Ocean, International Tribunal for the Law of the Sea, (ITLOS) Case No. 7.

65 Canada - Certain Measures Concerning Periodicals (1997), WTO Doc. WT/DS31/AB/R (Appellate Body Report); Mexico — Tax Measures on Soft Drinks and Other Beverages (2006), WTO Doc. WT/DS308/AB/R(Appellate Body Report), online: WTO <http://docsonline.wto.org/gen_search/asp>. 
deference to defiance. The protracted multitrack litigation reveals both co-operation and contestation, synergy and tension, and relationship and resistance among different tribunals. Space considerations preclude a systematic analysis of all litigation tracks of the Softwood Lumber dispute. Instead, this article highlights one extraordinary set of interactions among international and domestic fora that emphasizes the promise, potential pitfalls, and paradoxes implicated by litigation before international and domestic tribunals.

\section{The ZEROING SAGA}

Perhaps the most interesting set of interactions between international and domestic fora occurred in the context of Canada's challenge to the U.S.'s use of a particular methodology for calculating dumping duties. Anti-dumping law is highly technical; happily, for current purposes only a rudimentary understanding of the relevant law is sufficient. WTO law permits states to offset the price advantage that dumped goods enjoy though special tariffs known as anti-dumping duties. To do so, investigating authorities in the importing state must establish the "dumping margin," by calculating the difference between the normal value, usually the price on the exporter's home market, and the export price. In making this calculation, WTO rules require domestic authorities to conduct a "fair" comparison between the two prices. ${ }^{6}$

The U.S. DOC has for many years used a methodology known as "zeroing” when calculating dumping margins. Under this methodology, where sales in the home market are at prices above export prices, the difference is regarded as the "dumping margin" for that comparison. However, where sales occur in the home market at prices below the export price, the DOC does not calculate a "negative" dumping margin; rather, in these circumstances, the DOC deems these goods not to be dumped; in other words, the dumping margin for these sales is zero. The DOC then aggregates the results of these various comparisons. ${ }^{67}$ Critics argue that this method of calculating duties artificially inflates dumping duties. ${ }^{68}$

Foreign producers challenged the use of zeroing in U.S. courts. In Timken Co. v. United States, ${ }^{69}$ a Japanese producer argued that the use of zeroing violates the statutory requirement that the DOC engage in a "fair comparison" of export price and normal value. The Court of Appeals for the Federal Circuit examined the DOC's interpretation of the relevant statutory language under the two-step analysis set out in Chevron v. Natural Res. Def. Council. ${ }^{70}$ Under the Chevron test, federal courts grant significant deference to administrative agencies' reasonable interpretations of statutes. If a statute is clear and unambiguous, courts will strike contrary agency interpretations. ${ }^{71}$ However, if a statute is silent or ambiguous, then courts

66 For an excellent description of the WTO's anti-dumping regime, see Petros C. Mavroidis, Trade in Goods (Oxford: Oxford University Press, 2007) at 338-65.

67 For a detailed, yet accessible, explanation of zeroing, see Edwin Vermulst, The WTO Anti-Dumping Agreement (Oxford: Oxford University Press, 2005) at 51-61. 99 at 116 (noting “obvious distortion” produced by use of zeroing methology).

354 F.3d 1334 (Fed. Cir. 2004) [Timken].

467 U.S. 837 (1984) [Chevron].

Under this inquiry, courts must determine "whether Congress has directly spoken to the precise question at issue. If the intent of Congress is clear, that is the end of the matter; for the court, as well as the agency, must give effect to the unambiguously expressed intent of Congress” (ibid. at 842-43). 
will uphold agency determinations as long as they are reasonable interpretations of the statute. $^{72}$

Applying this test, the Court first found that Congress did not expressly require use of the zeroing in the anti-dumping statute. However, the Court found that use of zeroing was "a reasonable interpretation of the statute."73 Hence, when the most recent round of Softwood Lumber litigation began, zeroing had been upheld as a permissible agency interpretation of the relevant statutory language.

The Softwood Lumber dispute involved a series of challenges to this methodology. This litigation began, as described above, with the filing of a petition by domestic industry in 2002. Thereafter, using zeroing, the DOC made a preliminary determination that Canadian softwood lumber products were being sold at less than fair value (LTFV) prices, ${ }^{74}$ and then a final affirmative LTFV determination. ${ }^{75}$

Canada sought review before a NAFTA c. 19 binational panel. Canada raised a number of arguments, including that use of zeroing was inconsistent with WTO law. The NAFTA panel held that zeroing was permissible under U.S. law and that "WTO decisions are not binding upon Commerce or this Panel."76 However, the panel found that the DOC erred in several respects in the calculation of anti-dumping duties and remanded the matter with an order to the DOC to amend its final determination, or to furnish additional explanation for its actions. $^{77}$ On 15 October 2003, the DOC issued a remand determination. Canada appealed this determination to a binational panel. In a 5 March 2004 decision, the panel found that many of the DOC's determinations were supported by substantial evidence. However, it found that several determinations were not adequately supported, and again remanded. Significantly, the panel rejected a request to re-examine its decision on the use of zeroing on the basis of a pending WTO dispute. The panel reasoned that it had to "decide this case based on the law in effect; it cannot avoid decision based on the speculation of legal change."78 In

Ibid. at 843: "If the statute is silent or ambiguous with respect to the specific issue," however, "the question for the court is whether the agency's [interpretation] is based on a permissible [i.e., reasonable] construction of the statute.”

Timken, supra note 69 at 1342. Later cases reached the same conclusion: see e.g. Corus Staal BV v. Department of Commerce, 395 F.3d 1343 (Fed. Cir. 2005); Paul Muller Industrie GmbH \& Co. v. United States, 435 F.Supp. 2d 1241 (Ct. Int'l Trade 2006). Notice of Preliminary Determination of Sales at Less Than Fair Value and Postponement of Final Determination: Certain Softwood Lumber from Canada, 66 Fed. Reg. 56062 (6 November 2001).

75 Notice of Final Determination of Sales at Less Than Fair Value: Certain Softwood Lumber from Canada, 67 Fed. Reg. 15539 (2 April 2002). The Final Determination was accompanied by the publication of an Issues and Decision Memorandum, which described the basis for Commerce's Final Determination in detail. On May 22, 2002, Commerce published its Notice of Amended Final Determination of Sales at Less than Fair Value and Antidumping Duty Order: Certain Softwood Lumber from Canada, 67 Fed. Reg. 36068 (22 May 2002).

76 Re Certain Softwood Lumber Products from Canada: Final Affirmative Antidumping Determination, USA-CDA-2002-1904-02 (DOC), Decision of the Panel (17 July 2003) (Ch. 19 Panel), online: NAFTA Secretariat <http://nafta-sec-alena.org > at 60.

77 For example, the DOC was ordered to make certain adjustments to reflect dimensional differences between different softwood products being compared, to exclude certain products from its calculation, and to explain why it reached certain conclusions: ibid.

78 Re Certain Softwood Lumber Products from Canada: Final Affirmative Antidumping Determination, USA-CDA-2002-1904-02 (DOC), Decision of the Panel Respecting Remand Determination (5 March 2004), online: NAFTA Secretariat <http://nafta-sec-alena.org> at 34. 
July 2004, the panel found, for the third time, that the use of zeroing was a permissible application of the U.S. anti-dumping statute.

While it pursued the NAFTA litigation outlined above, Canada simultaneously challenged the DOC's use of zeroing at the WTO. ${ }^{79}$ A WTO panel held that the DOC's use of zeroing was inconsistent with WTO law; in August 2004, the WTO’s Appellate Body affirmed this determination. $^{80}$

Hence, by late 2004, the use of zeroing had been subject to sustained legal challenge: a U.S. Court of Appeals had held that zeroing was a permissible reading of the relevant U.S. statute, a series of NAFTA panels had later upheld use of zeroing, and the WTO's Appellate Body had held the zeroing methodology to be inconsistent with U.S. obligations under international trade law. In the face of these multiple holdings, what was the legal status of the DOC's use of zeroing in anti-dumping investigations?

After the Appellate Body's determination, Canada once again challenged the DOC's use of zeroing before the NAFTA panel. The panel faced an interesting issue of first impression. Should it again deem zeroing a permissible interpretation of the statute under the Chevron analysis? Or did the Appellate Body determination — even if technically not binding upon the NAFTA panel — change the analysis?

The binational panel invoked Murray v. Schooner Charming Betsy, an 1804 opinion by Marshall J. declaring that "an act of Congress ought never to be construed to violate the law of nations, if any other possible construction remains." ${ }^{81}$ In a detailed and lengthy analysis, the panel relied on the Charming Betsy principle, rather than the Chevron analysis, to conclude that the DOC was precluded from using the zeroing methodology, notwithstanding its own three earlier determinations, and a U.S. Court of Appeals holding, that zeroing was a permissible interpretation of the relevant statute. ${ }^{82}$ The holding represents a rather extraordinary instance of an international panel, sitting in effect as a domestic appellate court, interpreting domestic law to require the application of a decision by another international tribunal to trump a judicially-sanctioned interpretation by the domestic agency charged with administering the relevant statute.

A figure detailing the Softwood Lumber anti-dumping litigation can be found on page 341.

79 Softwood Lumber is not the only dispute to consider the WTO-legality of zeroing. See e.g. United States — Measures Relating to Zeroing and Sunset Reviews (2007), WTO Doc. WT/DS322/AB/R (Appellate Body Report); United States — Laws, Regulations and Methodology for Calculating Dumping Margins (2006), WTO Doc. WT/DS294/AB/R(Appellate Body Report); United States - Anti-Dumping Measure on Shrimp from Ecuador (2007), WTO Doc. WT/DS335/R (Panel Report), all decisions available online: WTO <http://docsonline.wto.org/gen_search/asp>.

$80 \quad$ United States — Final Dumping Determination on Softwood Lumber from Canada (2004), WTO Doc. WT/DS264/AB/R (Appellate Body Report), online: WTO <http://docsonline.wto.org/gen_search/asp>. 6 U.S. 64 at 118 (1804) [Charming Betsy].

Re Certain Softwood Lumber Products from Canada: Final Affirmative Antidumping Determination, USA-CDA-2002-1904-02 (DOC), Decision of the Panel Following Remand (9 June 2005) (Ch. 19 Panel), online: NAFTA Secretariat <http://nafta-sec-alena.org> [Decision of the Panel Following Remand]. 
strip in file: page 341.pdf (located on disk in Dunoff Charts folder) 


\section{SHOUlD DOMESTIC COURTS APPLy INTERNATIONAL TRIBUNAL DECISIONS?}

The abstract issue presented by the zeroing saga — the status of international law, particularly international tribunal decisions, in domestic courts - is one of the most controversial issues in contemporary U.S. jurisprudence. To oversimplify somewhat, the debate involves two schools of thought. One group, dubbed the "nationalists," is generally skeptical of domestic court use of international legal norms. Nationalists emphasize constitutional limitations on the domestic effect of international norms and generally urge that the political branches, rather than the courts, control the domestic implications of international legal obligations. ${ }^{83}$ A competing camp, the "internationalists," generally supports judicial application of international legal norms. This group views the domestic judiciary as part of a "global community of courts," and highlights the value of international judicial dialogue. ${ }^{84}$ Many international trade scholars fall within the internationalist camp, and in particular urge the domestic judicial application of WTO norms. ${ }^{85}$

But the Softwood Lumber litigation can be read as implicitly suggesting a reason why committed internationalists may not want domestic courts to apply international legal norms, at least in certain contexts. ${ }^{86}$ In one sense, the question before the NAFTA Softwood Lumber panel was relatively easy. The WTO litigation that held zeroing to be GATT-inconsistent involved precisely the same fact pattern and the same DOC investigation as that before the Softwood Lumber panel. ${ }^{87}$ Hence, the Softwood Lumber litigation involved the straightforward application of settled WTO law. But it is easy to imagine more difficult cases in which domestic courts are asked to interpret and to apply international trade law norms. For example, suppose the WTO Appellate Body holds a certain zeroing methodology impermissible in a preliminary dumping determination; should a domestic court extend this holding to use of that particular methodology in a final anti-dumping determination? Or to use of that methodology in a sunset investigation? Or to a slightly different zeroing methodology?

As these questions suggest, if domestic courts were to consider themselves required to interpret and apply WTO holdings, domestic courts would soon find that they were active

83 Curtis A. Bradley, “The Federal Judicial Power and the International Legal Order” (2006) 2006 Sup. Ct. Rev. 59; Curtis A. Bradley \& Jack L. Goldsmith, "Federal Courts and the Incorporation of International Law,” Commentary, (1998) 111 Harv. L. Rev. 2260; Curtis A. Bradley \& Jack L. Goldsmith, “Customary International Law as Federal Common Law: A Critique of the Modern Position” (1997) 110 Harv. L. Rev. 815.

84 See e.g. Jenny S. Martinez, “Towards an International Judicial System” (2003) 56 Stan. L. Rev. 429; Anne-Marie Slaughter, “Judicial Globalization” (2000) 40 Va. J. Int’l L. 1103; Harold Hongju Koh, “Transnational Legal Process” (1996) 75 Neb. L. Rev. 181.

85 For discussions, see Piet Eeckhout, “Judicial Enforcement of WTO Law in the European Union - Some Further Reflections” (2002) 5 J. Int’l Econ. L. 91; Jan Klabbers “International Law in Community Law: The Law and Politics of Direct Effect” (2002) 21 Y.B. Eur. L. 263; Naboth van den Broek, "Legal Persuasion, Political Realism, and Legitimacy: the European Court's Recent Treatment of the Effect of WTO Agreements in the EC Legal Order” (2001) 4 J. Int’l Econ. L. 411; Geert A. Zonnekeyn "The status of WTO law in the Community legal order: some comments in the light of the Portuguese Textiles case” (2000) 25 Eur. L. Rev. 293; Thomas Cottier \& Krista Nadakavukaren Schefer, “The Relationship Between World Trade Organization Law, National and Regional Law” (1998) 1 J. Int’l Econ. L. 83. I elaborate upon this argument in more detail elsewhere. See Jeffrey L. Dunoff, (2007) “Death, Dumping and Domestic Courts” [unpublished, archived with author].

87 Decision of the Panel Following Remand, supra note 82 at 40. 
creators, rather than passive recipients, of WTO law. Moreover, if international trade law had direct effect in domestic courts, a bevy of domestic courts would displace the WTO's Appellate Body as the sole tribunal that authoritatively interprets and applies WTO law. Direct effect would, in effect, prompt a shift from a highly centralized system centered upon the WTO's Appellate Body to a highly decentralized system with decisions emanating from the courts of the WTO's 150 members. This shift would likely produce different readings of WTO law in different jurisdictions.

Moreover, given the size of the U.S. market, the complexity of U.S. trade statutes, and the creativity of the U.S. trade law bar, the decision to grant international trade law direct effect would likely result in U.S. courts becoming de facto the lead judicial bodies interpreting WTO law. These courts might well produce an "international” trade law with an "American accent.”

For these reasons, internationalists who generally urge domestic courts to utilize international tribunal decisions might consider whether they prefer uniform interpretation by a specialized tribunal, or domestic application with the probability of doctrinal disarray, and a corresponding shift of law-making power from the WTO regime to national courts around the world. In this context, at least, internationalists might well conclude that domestic court application of international tribunal decisions is not desirable.

\section{The Challenge of Selective And Halting Compliance}

The third challenge that the Softwood Lumber dispute highlights is that of selective and halting compliance by powerful states. This problem is well-illustrated by the litigation over the ITC's finding that Canadian softwood lumber imports threatened material injury to the U.S. industry. To summarize the highly convoluted litigation over this issue, on 23 May 2001, the ITC published its preliminary determination that the U.S. softwood lumber industry was threatened with material injury by reason of imports of Canadian softwood lumber. ${ }^{88} \mathrm{On}$ 16 May 2002, the Commission unanimously confirmed its preliminary findings, ${ }^{89}$ and shortly thereafter, the DOC imposed countervailing and anti-dumping duties on Canadian softwood lumber. ${ }^{90}$ Canada immediately sought review of the injury determination by a NAFTA c. 19 binational panel. At the conclusion of a lengthy and critical review of the Commission's conduct, the binational panel wrote:

The Panel is particularly troubled by the extensive lack of analysis undertaken by the Commission of the factors applicable to a determination of whether there is a threat of material injury to the domestic softwood lumber industry.... [T] ]he Commission made its threat determination on the basis of considerable speculation and conjecture, the result of which conflicts not only with the agency's statutory mandate, but also with the rationale underlying its present material injury determination, as well as the record evidence.

Certain Softwood Lumber from Canada, 67 Fed. Reg. 36068 (22 May 2002).

$90 \quad$ Notice of Amended Final Affirmative Countervailing Duty Determination and Notice of Countervailing Duty Order: Certain Softwood Lumber Products From Canada, 67 Fed. Reg. 36070 (22 May 2002). 
Based on the foregoing, we conclude that the Commission's holding that the domestic softwood lumber industry is threatened with material injury ... is unsupported by substantial evidence and not in accordance with law. 91

Accordingly, the panel remanded to the Commission with a series of specific and detailed instructions.

The ITC undertook a second analysis and, on 15 December 2003, issued its remand determination. Once again, the Commission found that the U.S. softwood lumber industry was threatened with material injury by reason of imports of Canadian softwood lumber. ${ }^{92}$ Canada again sought review by the binational panel. Once again, the panel rejected and sharply criticized the Commission's analysis. The panel remanded to the Commission, and again provided specific and detailed instructions to the Commission. ${ }^{93}$

In response, the ITC undertook another analysis. Yet again, the Commission found that the U.S. softwood lumber industry was threatened with material injury by reason of imports of Canadian softwood lumber. ${ }^{94}$ Once again, Canada sought review before the binational panel. By this time, the panel had lost patience with what it viewed as the ITC's willful failure to undertake an appropriate analysis:

\begin{abstract}
In its Second Remand Determination, the Commission has refused to follow the instructions [we provided] in the First Panel Remand Decision. The Commission relies on the same record evidence that this Panel not once, but twice before, held insufficient as a matter of law to support the Commission's affirmative threat finding... The Commission has made it abundantly clear to this Panel that it is simply unwilling to accept this Panel's review authority under Chapter 19 of the NAFTA and has consistently ignored the authority of this Panel in an effort to preserve its finding of threat of material injury. This conduct obviates the impartiality of the agency decision-making process, and severely undermines the entire Chapter 19 panel review process. ${ }^{95}$
\end{abstract}

The panel concluded that it would be "an exercise in futility" to remand the matter to the Commission yet again, given that the Commission had "made it clear that it refuses to make a negative threat finding based on the record evidence." ${ }^{\text {"96 }}$ Hence, the panel "specifically preclude[d]"97 the Commission from undertaking another analysis of the substantive issues.

Re Certain Softwood Lumber Products from Canada: Final Affirmative Threat of Material Injury Determination, USA-CDA-2002-1904-07 (ITC), Decision of the Panel (5 September 2005) (Ch. 19 Panel), online: NAFTA Secretariat <http://nafta-sec-alena.org> at 107, 110.

Softwood Lumber From Canada, Inv. Nos. 701-TA-414 and 731-TA-928 (Final, Remand), USITC Pub. 3658 (December 2003).

Re Certain Softwood Lumber Products from Canada: Final Affirmative Threat of Injury Determination, USA-CDA-2002-1904-07 (ITC), Remand Decision of the Panel (19 April 2004) (Ch. 19 Panel), online: NAFTA Secretariat <http://nafta-sec-alena.org>.

Softwood Lumber From Canada, Inv. Nos. 701-TA-414, 731-TA-928 (Final, Second Remand), USITC Pub. 3715 (June 2004).

Re Certain Softwood Lumber Products from Canada: Final Affirmative Threat of Material Injury Determination, USA-CDA-2002-1904-07 (ITC), Second Remand Decision of the Panel (31 August 2004) (Ch. 19 Panel), online: NAFTA Secretariat <http://nafta-sec-alena.org > at 3 [footnotes omitted]. Ibid. at 4.

Ibid. at 4, 7. 
Instead, the panel took the extraordinary measure of ordering the Commission, within ten days, to make a finding that "the record does not support a finding of threat of material injury."98

On 10 September 2004, the Commission responded. ${ }^{99}$ It protested that the Panel's actions were inconsistent with its mandate and in excess of its authority: "the proper role of the Panel is not to review the evidence de novo and make its own factual findings.... [T] authority provided to the Panel under the [NAFTA] simply does not permit the Panel to refind the evidence and compel a negative determination." 100 The Commission also argued that it faithfully followed the Panel's remand instructions after both the first and second remands. However, the ITC continued:

\begin{abstract}
Because the Commission respects and is bound by the NAFTA dispute settlement process, we issue a determination ... that the U.S. softwood lumber industry is not threatened with material injury by reason of subject imports from Canada. In so doing, we disagree with the Panel's view that there is no substantial evidence to support a finding of threat of material injury and we continue to view the Panel's decisions throughout this proceeding as overstepping its authority, violating the NAFTA, seriously departing from fundamental rules of procedure, and committing legal error. ${ }^{101}$
\end{abstract}

On 12 October 2004, the NAFTA binational panel affirmed this determination. ${ }^{102}$

One might view this as a story of U.S. compliance; after all, the NAFTA panel ruled that there was no threat of injury and, eventually, U.S. officials adopted this ruling. But this would surely be an incomplete, if not misleading, characterization of the U.S. approach to the injury issue. First, the "compliance" that eventually obtained was slow, expensive, and reluctant. More importantly, while the litigation described above was proceeding, the ITC's injury determinations were also challenged at the WTO. A WTO panel determined that the ITC's threat of injury determination was GATT-inconsistent. ${ }^{103}$ A subsequent ITC determination again found threat of material injury; Canada challenged this finding, and a

Ibid. at 7,13 .

"Views of the Commission in Response to the Panel Decision and Order of August 31, 2004," online: Foreign Affairs and International Trade Canada <http://www.dfait-maeci.gc.ca/eicb/softwood/pdfs/ITC September10RemandDetermination.pdf $>$.

Ibid. at 2 .

Ibid. at 13-14 [footnotes omitted].

Re Certain Softwood Lumber Products from Canada, USA-CDA-2002-1094-07, Panel Decision (12 October 2004) (Ch. 19 Panel), online: NAFTA Secretariat <http://nafta-sec-alena.org>. However, this decision did not end the litigation. First, on 24 November 2004, the U.S. filed a request for an Extraordinary Challenge Committee (EEC) to review and vacate the panel's decisions. The NAFTA provides for EECs to act as a safety net to deal with mistakes that are so egregious as to undermine the functioning and acceptance of the entire c. 19 process and, even then, only if such mistakes "materially affected the panel's decision and threatens the integrity of the binational panel review process": NAFTA, supra note 26, c. 19, art. 1904(13)(b). The U.S. raised three issues before the EEC. After carefully considering the U.S. arguments, the EEC denied the challenge and affirmed the decisions of the NAFTA binational panel. Second, following the litigation discussed in text, the U.S. took the position that it would not refund the duties that Canadian producers had been paying for years based, in part, on the ITC's erroneous threat of material injury finding. This issue gave rise to federal court litigation and was eventually resolved by the 2006 SLA.

United States - Investigation of the International Trade Commission in Softwood Lumber from Canada (2004), WTO Doc. WT/DS277/R (Panel Report), online: WTO <http://docsonline.wto.org/ gen_search/asp>. 
WTO panel upheld the ITC's determination. ${ }^{104}$ On appeal, the panel's decision was vacated. However, the U.S. took the position that, notwithstanding the ITC's negative threat of injury determination as a result of the NAFTA litigation, the WTO panel's decision upholding an ITC finding of injury permitted the U.S. to continue to collect duties on Canadian softwood lumber. ${ }^{105} \mathrm{~A}$ figure detailing this litigation can be found on page 347.

Perhaps more troublingly, stepping back from the particulars of the various litigation, we might understand the entire Softwood Lumber saga as involving decades of litigation where the U.S. lost on virtually every major issue; nevertheless due, in part, to U.S. recalcitrance, the two states negotiated a settlement that institutionalizes a system of managed trade that significantly limits sales of Canadian softwood lumber into the U.S. The U.S. conduct in the Softwood Lumber litigation can be seen as an instantiation of a larger compliance problem that faces dispute settlement mechanisms in the trade realm. As a general matter, compliance rates with WTO panels is quite good overall. ${ }^{106}$ However, there are exceptions to this generalization and, as an empirical matter, a substantial number of the cases involving longterm non-compliance or non-implementation involve the most powerful WTO members, the EU and, more frequently, the U.S.

One indicia of the shadow that powerful state non-compliance casts upon the dispute system can be found in so-called art. 21.5 actions under the DSU at the WTO. Under WTO dispute settlement, losing parties are supposed to withdraw or amend the measures challenged in WTO dispute settlement. The system permits prevailing parties to challenge the adequacy of actions taken by losing parties in art. 21.5 compliance actions. As of 23 April 2007, some 363 complaints had been notified to the WTO, and 102 panel and Appellate Body reports had been adopted. Of these disputes, approximately 19 involved art. 21.5 compliance actions. Of these 19 disputes, no less than 15, or 78 percent, involved either the U.S., the EU, or Canada as the allegedly non-complying party. The U.S. was respondent in 11 , or 58 percent of these actions. In a majority of these disputes, it was determined that compliance had not occurred. ${ }^{107}$

United States - Investigation of the International Trade Commission in Softwood Lumber from Canada - Recourse to Article 21.5 of the DSU by Canada (2005), WTO Doc. WT/DS277/RW (Panel Report), online: WTO <http://docsonline.wto.org/gen_search/asp>. Canada appealed the art. 21.5 panel decision to the Appellate Body and the Appellate Body reversed the art. 21.5 panel decision: United States Investigation of the International Trade Commission in Softwood Lumber from Canada - Recourse to Article 21.5 of the DSU by Canada (2006), WTO Doc. WT/DS277/AB/RW (Appellate Body Report), online: WTO <http://docsonline.wto-org/gen_search/asp>. But the Appellate Body was unable to complete the analysis to determine whether the U.S.'s redetermination was consistent with the $A D$ and CVD Agreements, noting that there was an absence of relevant factual findings by the panel. It bears noting that, although the WTO and NAFTA findings are divergent, they are not necessarily inconsistent. The NAFTA panel sits, in effect, as a U.S. tribunal and applies U.S. domestic trade law. The WTO panel, in contrast, applies WTO law.

See Bruce Wilson, "Compliance by WTO Members with Adverse WTO Dispute Settlement Rulings: The Record to Date," Comment, (2007) 10 J. Int'l Econ. L. 397 (reviewing the "overall positive record" of compliance after adverse panel reports).

Statistics derived from data found in Update of WTO Dispute Settlement Cases (2007), WTO Doc. WT/DS/OV/30, online: WTO <http://docsonline.wto.org/gen_search/asp>. 
strip in file: page 347.pdf (located on disk in Dunoff Charts folder) 
The most recent example of problematic U.S. compliance is the gambling dispute. This case involves a challenge by Antigua to several federal and state statutes that, in effect, make it illegal to operate internet-based gambling services. Antigua alleged that these various laws violated U.S. commitments under the General Agreement on Trade in Services. ${ }^{108}$ A WTO panel held that the challenged laws violated U.S. GATS commitments, ${ }^{109}$ and the Appellate Body affirmed, albeit on narrower grounds. ${ }^{110}$ In their recommendations and rulings, both the panel and the Appellate Body requested the U.S. to bring its measures found to violate the GATS into conformity with its obligations under that Agreement.

On 19 May 2005, the U.S. stated that it intended to implement these recommendations and rulings and had begun to evaluate its options for doing so. The U.S. also stated that it would need a reasonable period of time in which to do this. After negotiations, however, Antigua and the U.S. were unable to agree on a reasonable period of time. The issue was submitted to binding WTO arbitration, and the arbitrator gave the U.S. until 3 April 2006, to come into compliance. ${ }^{111}$

In March 2006, the U.S. reported to the WTO that "[the] Administration, in consultation with the U.S. Congress, has been working on appropriate steps to resolve this matter." ${ }^{\text {112 }} \mathrm{On}$ 10 April 2006, the U.S. reported that it was in compliance. Significantly, the U.S. claim of compliance did not rest on new legislation, new regulations, or a new judicial interpretation of the challenged laws. Instead, the U.S. rested its claim of compliance on testimony given by a Department of Justice official at a hearing before the House of Representatives, in which the official gave an interpretation of the relevant U.S. law identical to the interpretation that the U.S. had argued before the WTO panel and Appellate Body. ${ }^{113}$

Not surprisingly, Antigua did not think that the reiteration of a legal interpretation that had previously been rejected by a WTO panel constituted compliance, and instituted art. 21.5 proceedings against the U.S. The compliance panel had little difficulty in rejecting the U.S. position:

There has been no change to any of [the challenged laws] since the original proceeding. There has been no change in the application of these three measures, or even their interpretation, since the original proceeding. There is no evidence of any changed in the factual or legal background bearing on these measures or their

15 April 1994, 1869 U.N.T.S. 183, 33 I.L.M. 1167 (entered into force 1 January 1995) [GATS].

United States - Measures Affecting the Cross-Border Supply of Gambling and Betting Services (2004), WTO Doc. WT/DS285/R (Panel Report), online: WTO <http://docsonline.wto.org/ gen_search/asp>. United States - Measures Affecting the Cross-Border Supply of Gambling and Betting Services (2005), WTO Doc. WT/DS285/AB/R (Appellate Body Report), online: WTO <http://docsonline. wto.org/gen_search/asp>.

United States - Measures Affecting the Cross-Border Supply of Gambling and Betting Services, (2005) WTO Doc. WT/DS285/13 (Arbitration under Article 21.3(c)), online: WTO <http:// docsonline.wto.org/gen_search/asp>.

See United States - Measures Affecting the Cross-Border Supply of Gambling and Betting Services Recourse to Article 21.5 by Antigua and Barbuda (2007), WTO Doc. WT/DS285/RW (Panel Report), online: WTO <http://docsonline.wto.org/gen_search/asp>.

Ibid. 
effects since the original proceeding that might have brought them into compliance. This indicates that they remain inconsistent with the United States' obligations under the GATS. ${ }^{114}$

To be sure, discussion of U.S. non-compliance in particular disputes must be kept in context. The U.S. is overrepresented in compliance disputes, in part, because the U.S. is the most frequent target of WTO complaints; moreover, it is important to note that the U.S. has complied with many, but by no means all, adverse reports. Nevertheless, U.S. compliance in a number of high-profile cases has been problematic. In cases such as FSC, the 1916 AntiDumping Act, and the Byrd Amendment dispute, ${ }^{115}$ U.S. non-compliance has created significant international tensions. ${ }^{116}$

Moreover, the concern here has less to do with U.S. actions in the gambling dispute - or any other particular case - that with the larger pattern that emerges. U.S. non-compliance is troublesome, in part, because the U.S. is the most frequent user of the system. In cases where it prevails, the U.S. cannot credibly demand that other states comply if it does not comply with adverse decisions. But the problem is broader than a simple concern with reciprocity. The U.S. was the principle demandeur of the WTO's innovative dispute system; many other states agreed to this system with great reluctance. Under these circumstances, it is likely that U.S. non-compliance will be perceived by other states as signaling a weakening commitment to the system, and this may prompt higher rates of non-compliance by other states. Once non-compliance rates reach a certain threshold, confidence in the system will erode. Unfortunately, the U.S. actions in the Softwood Lumber litigation illustrate the type of non-compliance that threatens confidence in supranational dispute settlement systems.

\section{CHALLENGES TO THE INTERNATIONAL SYSTEM}

The central aim of this article is to argue that the significance of the Softwood Lumber dispute transcends the particulars of this complex row between two usually friendly neighbours. The dispute is important because it highlights three of the most difficult challenges facing the trade system, namely (i) the dramatic proliferation of preferential trade agreements and their relationship with the multilateral system; (ii) the problem of parallel litigation among multiple domestic and international dispute resolution fora; and (iii) selective and halting compliance by powerful states. However, these challenges are not unique to the international trade system. Rather, the challenges facing the trade system can

$114 \quad$ United States - Measures Affecting the Cross-Border Supply of Gambling and Betting Services Recourse to Article 21.5 of the DSU by Antigua and Barbuda (2007), WTO Doc. WT/DS285/RW at para. 6.27 (Panel Report), online: WTO <http://docsonline.wto.org/gen_search/asp>.

United States - Tax Treatment for "Foreign Sales Corporations" (2000), WTO Doc. WT/DS108/AB/R (Appellate Body Report); United States - Antidumping Act of 1916 (2000), WTO Doc. WT/ DS136/AB/R (complaint by the European Communities), WTO Doc. WT/DS162/AB/R (complaint by Japan) (Appellate Body Report); United States - Continued Dumping and Subsidy Offset Act of 2000 (2003), WTO Doc. WT/DS217/AB/R (Appellate Body Report), online: WTO <http:// docsonline.wto.org/gen_search/asp>.

On the other hand, the U.S. has complied in some politically charged cases, notably the contentious dispute involving steel safeguards. However, in terminating the steel safeguards, President George W. Bush did not acknowledge the adverse WTO panel and Appellate Body reports. Instead, he argued that the restructuring of the steel industry constituted "changed economic circumstances" that justified termination of the steel tariffs: see "Presidential Proclamation No. 7741” (8 December 2003) 68 Fed. Reg. 68483. 
be understood as instantiations of three of the most difficult structural issues facing the larger public international law system, namely (i) the fragmentation of international law; (ii) the relationships among proliferating international tribunals; and (iii) the limits to the legalization of international relations. As these challenges have been extensively analysed elsewhere, each is only briefly outlined below.

\section{A. THE FRAGMENTATION OF INTERNATIONAL LAW}

One of the most striking aspects of contemporary international law is the emergence and development of entirely new international law fields and the increasing sophistication of many new and existing fields. These trends seemed to accelerate during the late 1980s and 1990s, leading many prominent scholars to declare that international law had finally entered a "post-ontological” age and to celebrate the "legalization of international relations." 117 But international law's triumphalist moment quickly faded. Ironically, some of the developments that seemed so promising a decade ago appear deeply problematic today. Prominent among these is a concern that the expansion and diversification of international norms and institutions has produced a "fragmentation" of international law. ${ }^{118}$

Treatises and scholarship from the early- and mid-20th century would have suggested that international law consisted entirely of the Law of Peace and the Law of War. ${ }^{119}$ Since then, numerous new substantive areas have emerged as important parts of the discipline, including human rights, international environmental law, international investment, intellectual property, and the law of development. However, in recent years, many have expressed concern that the emergence of specialized and relatively autonomous spheres of legal rules, institutions, and practices may be producing a splintering or "fragmentation" of international law. ${ }^{120}$ As a result of this fragmentation, activities that formerly were subject to "general international law” now fall within specialized systems such as trade law, human rights law, environmental law, law of the sea, investment law, refugee law, and the like.

Each of these areas of law has its own treaties, principles, and institutions, all designed to advance certain values. However, the values advanced by any one regime are not necessarily consistent with those of other specialized regimes. In practice, specialized law making, institution building, and dispute resolution in any particular field tends to occur in relative ignorance of developments in adjoining fields, risking conflicting jurisprudence, inconsistent judgments, and loss of legal security. Thus, just as trade law is forced to grapple with the challenge posed by increasing numbers of PTAs and the challenge they pose to the coherence of the multilateral trading system, so too public international law must grapple

Thomas M. Franck, Fairness in International Law and Institutions (New York: Oxford University Press, 1995) (announcing arrival of international law's "post-ontological age”); Judith Goldstein et al., "Introduction: Legalization and World Politics” (2000) 54 International Organization 385. Fragmentation of International Law: Difficulties Arising from the Diversification and Expansion of International Law, Report of the Study Group of the International Law Commission 6, UN Doc. A/CN.4/L.702 (July 18, 2006); Martti Koskenniemi \& Päivi Leino, "Fragmentation of International Law? Postmodern Anxieties” (2002) 15 Leiden J. Int’l. L. 553. 
with the challenge posed by proliferating, and often conflicting, international legal regimes, and the challenge they pose to the coherence of the international legal order.

A recent example illustrates these concerns. In December 2001, the United Kingdom government authorized the commissioning of a nuclear plant at Stellafield to produce mixed oxide (MOx) fuel from a mixture of reprocessed plutonium dioxide and uranium dioxide. The plant is just over 100 miles away from Ireland, and the Irish government has long been concerned about discharges of radioactive material into the Irish Sea. In an effort to halt operations, Ireland unleashed a series of suits against the U.K. before multiple international tribunals. ${ }^{121}$ In particular, Ireland filed legal challenges based on the potential environmental effects of the MOx plant before an arbitral tribunal set up under the United Nations Convention on the Law of the Sea; ${ }^{122}$ the European Court of Justice (ECJ), under European Community (EC) law; and a tribunal constituted under dispute settlement procedures of the Convention for the Protection of the Marine Environment of the North-East Atlantic. ${ }^{123}$ Arguably, the nuclear facility is governed by all three international legal regimes; arguably, the different regimes impose different legal obligations on the relevant parties. Which set of norms should prevail? More broadly, how are these diverse regimes related, and which principles should be used to resolve potential conflicts among them?

We might understand the Softwood Lumber litigation as illustrating the fragmentation of a dispute, as various dimensions of the case were litigated under trade law as applied by domestic agencies, NAFTA panels, and WTO dispute settlement fora. But the MOx dispute illustrates the fragmentation of the international legal order, as various dimensions of the dispute were litigated under entirely different legal regimes. International disputes that involve multiple legal regimes are increasingly common, and, at present, the international legal system lacks effective doctrinal and institutional mechanisms to address this form of fragmentation.

\section{B. The Challenges Posed By Multiple InTernational Tribunals}

The Softwood Lumber dispute highlights a second challenge facing the international trade system, namely the difficulties associated with parallel litigation before multiple dispute resolution bodies. As described in detail above, the dispute involved multiple issues of law and fact that came repeatedly before both domestic and supranational tribunals, as well as complex issues involving the relationships among these tribunals. Once again, however, this challenge facing the trade system can be understood as an instantiation of a similar challenge facing the public international law system. However, the public international law variation of this challenge is, if anything, even more complex than the interactions among different trade tribunals present in the Softwood Lumber litigation.

In much the same way that international law has experienced a proliferation of specialized functional regimes, such as human rights, trade, and investment, so too has it experienced 
a proliferation of international tribunals, which now exceed one hundred. ${ }^{124}$ The proliferation of tribunals has been accompanied by a dramatic increase in international litigations. The rise in caseloads is particularly striking for the European Court of Human Rights (ECHR) and $\mathrm{ECJ},{ }^{125}$ but is also true for tribunals ranging from the International Court of Justice and the Inter-American Court of Human Rights. ${ }^{126}$ Indeed a recent study concluded that "roughly $70 \%$ of the total international judicial activity and rulings have come in the past 14 years alone." 127 The number of international arbitrations has likewise increased dramatically over the last decade; much of this growth is the result of a sharp increase in the number of investment treaties, which mushroomed from about 500 treaties in 1992, to over 2,000 in 2001, to over 2,500 treaties today. ${ }^{128}$ Moreover, it is likely that the increase in cases will continue; whereas previously international courts predominantly addressed claims filed by states against other states, international courts increasingly grant access to non-state entities, including individuals, which tends to increase the number of cases filed. ${ }^{129}$

As international tribunals reach a critical mass, they have begun to interact with one another, and with national courts, much more frequently. As the Softwood Lumber dispute illustrates, multiple tribunals may exercise concurrent jurisdiction over different aspects of the same dispute, and courts interact iteratively over time as they interpret and apply the same bodies of substantive law. However, at present the international legal system lacks even the most rudimentary rules relating to fundamental structural issues, such as overlapping or concurrent jurisdiction, the res judicata or collateral estoppel effects of decisions, and the enforcement of judgments. As international disputes proliferate, and as they are brought before multiple bodies, bringing some coherence to the practice of international tribunals is an enormously challenging task facing the international legal system.

124 On the proliferation of international courts and tribunals, see e.g. Yuval Shany, The Competing Jurisdictions of International Courts and Tribunals (Oxford: Oxford University Press, 2003); Symposium Issue: The Proliferation of International Tribunals: Piecing Together the Puzzle (1999) 31 N.Y.U. J. Int'l L. \& Pol. 679.

See Laurence R. Helfer \& Anne-Marie Slaughter, "Why States Create International Tribunals: A Response to Professors Posner and Yoo” (2005) 93 Cal. L. Rev. 899 at n. 47, citing Karen J. Alter, "Delegation to International Courts: Why, How, and Problems in Doing So" (Paper prepared for the Conference on Delegation to International Organization, Park City, Utah, 3-4 May 2002) [unpublished]: Of the 2090 infringement cases referred by the European Commission to the ECJ between its founding in 1952 and 2002, 1366 or approximately 65\% were referred to the court between 1990 and 2002. A similar trend is apparent for the 4834 cases referred to the ECJ by national courts, of which 2945 or approximately $61 \%$ were referred during that thirteen-year period. Caseload figures for the ECHR are even more striking. Of the 259,891 cases registered and 3442 judgments issued by the ECHR since 1959, 210,769 cases (approximately 81\%) and 3304 judgments (approximately 96\%) were registered and issued, respectively between 1990 and 2002.

Helfer \& Slaughter, ibid. at n. 48, citing Alter, ibid. at 5: "Since its inception in 1979, the IACHR has issued 97 judgments, 17 advisory opinions, and 148 orders for provisional measures. It issued 88 judgments, 7 advisory opinions, and all of its provisional measures orders between 1990 and 2002, inclusive."

Karen J. Alter, “Private Litigants and the New International Courts” (2006) 39 Comparative Political Studies 22 at 23.

UN Conference on Trade and Development, Developments in International Investment Agreements in 2005 (2006) I.I.A. Monitor No. 2, UNCTAD/WEB/ITE/IIA/2006/7.

Laurence R. Helfer \& Anne-Marie Slaughter, "Toward a Theory of Effective Supranational Adjudication” (1997) 107 Yale L.J. 273 at 276. 


\section{THE Limits OF LEgALIZATION}

The third challenge to the trade regime, that of selective and halting compliance by powerful states, is an instantiation of perhaps the largest problem facing international law: the problem of the limits of legalization. The 1990s witnessed a strong move towards the legalization of international relations. However, in the aftermath of the 11 September 2001, terrorist attacks, realist approaches to international relations — which minimize the role of international law - have been ascendant in many states and international law has been a discipline under severe stress. In particular, the planet's sole superpower has recently had a decidedly uneasy relationship with international legal norms, as illustrated by the U.S. refusal to ratify the Kyoto Protocol, ${ }^{130}$ unsigning of the Rome treaty, ${ }^{131}$ rejection of the landmines treaty, ${ }^{132}$ and its repudiation of the ABM treaty ${ }^{133}$ - not to mention its articulation of a theory of the norms governing use of force that is in considerable tension with conventional understandings.

In short, despite the recent proliferation of norms, institutions, and tribunals, contemporary international law appears to be a discipline under siege. Kofi Annan has stated that, given recent trends, international law and institutions face "a fork in the road" as momentous as that faced in 1945, when the post-World War II order was built ${ }^{134}$ and warned that we "can no longer take it for granted that our multilateral institutions are strong enough to cope with all of the challenges facing them."135 More pessimistically, Thomas Franck observes that "in the new millennium, after a decade's romance with something approximating law-abiding state behaviour, the law-based system is once again being dismantled." "136 And, as if to underscore the point, recent developments in the Softwood Lumber saga serve to underline the limits international law's ability to manage international conflict.

Shortly after the U.S. and Canada finalized the 2006 SLA, the two sides agreed to delay the agreement's implementation date. Some in the U.S. viewed this as a tactic by Canadian industry to "flood" the U.S. market before the terms of the deal took effect. Almost immediately after the agreement came into force, the U.S. raised concerns over several issues that might constitute violations of Canadian commitments. In February 2007, at the inaugural meeting of the Softwood Lumber Committee, the U.S. complained about pledges of financial assistance that the Quebec and Ontario governments made to their lumber industries. In late

Kyoto Protocol to the United Nations Framework Convention on Climate Change, 11 December 1997, UN Doc. FCCC/CP/1997/7/Add.1, 37 I.L.M. 22 (entered into force 16 February 2005).

Rome Statute of the International Criminal Court, 17 July 1998, 37 I.L.M. 999.

Convention on the Prohibition of the Use, Stockpiling, Production and Transfer of Anti-Personnel Mines and on Their Destruction, 12 September 1997, online: <http://untreaty.un.org/English/ millennium/law/disarmament/xxvi_5E.htm>.

Treaty on the Limitation of Anti-Ballistic Missile Systems, U.S.-U.S.S.R., 26 May 1972, 944 U.N.T.S. 13, 23 U.S.T. 3435. See also “Announcement of Withdrawal from the ABM Treaty," online: <http://www.state.gov/t/ac/rls/fs/2001/6848.htm> (invoking the withdrawal provision in article XV(2) of the ABM treaty).

Kofi A. Annan, Speech to the UN General Assembly (23 September 2003), online: <http://www.unausa. org/aboutus/annan092393.asp>.

Implementation of the United Nations Millennium Declaration, Report of the Secretary-General (2003), UN Doc. A/58/323 at para. 4.

Thomas M. Franck, “What Happens Now? The United Nations After Iraq” (2003) 97 Am. J. Int’l L. 607 at 608 . 
March 2007, the U.S. requested formal consultations with Canada regarding several federal and provincial programs, as well as Canada's interpretation of the Agreement's provisions adjusting export levels, including the level triggering the Agreement's mechanism on import surges. ${ }^{137}$ It appears that these issues are still outstanding. ${ }^{138}$

Hence, the Softwood Lumber dispute helps to highlight one of the central issues facing the discipline of international law. Despite the dramatic increase in the number and scope of international norms, we lack a satisfactory account of when or how these norms change state behavior. ${ }^{139}$ In addition, notwithstanding the proliferation of supranational tribunals and the increase in their caseloads, it is not clear whether or how these tribunals enhance compliance with international legal norms. ${ }^{140}$ These observations are not intended to underestimate the important contributions that international rules and institutions make in stabilizing expectations, disseminating information, reducing bargaining and transaction costs, and reviewing state behavior. But they do suggest that, despite the impressive and welcome gains toward the legalization of international relations, international law still remains one of many factors that influences international affairs and that the submission of a dispute to legal mechanisms is simply one of many factors that determines whether any particular dispute will be successfully managed or resolved.

\section{FAIR TRADE: \\ THE RELATiOnS AMONG DivERSE INTERNATIONAL LEGAL REgIMES}

By using the phrase "Free Trade or Fair?" in the Symposium's title, the Symposium organizers allude to yet another set of issues implicated by the Softwood Lumber dispute. The increasing penetration of international trade into domestic economies, and the increased reach of international trade rules into domestic regulatory systems, has sparked heated debates over what constitutes "fair" trade. Many contemporary trade disputes involve national culture, sovereignty, and other complex issues that are not easily amenable to political bargaining and compromise solutions.

Of these "fair trade" issues, perhaps the most attention has been focused on issues of labour standards, human rights, and environmental protection. These issues first came to light in the early 1990s as the U.S., Canada, and Mexico were negotiating the NAFTA, and with the leaking of a GATT panel report concluding that a U.S. ban on tuna caught using methods that killed large numbers of marine mammals was GATT-inconsistent. ${ }^{141}$ These events sparked a contentious debate over whether liberalized trade promoted unsustainable

The U.S. request for arbitration can be found online: USTR <http://www.ustr.gov/assets/Trade Agreements/Monitoring_Enforcement/2006_Softwood_Lumber_Agreement/asset_upload_file465_ 13242.pdf>. The U.S. Statement of the Case can be accessed online: USTR <http://www.ustr.gov/ assets/Trade_Agreements/Monitoring_Enforcement/2006_Softwood_Lumber_Agreement/asset_ upload_file844_13393.pdf>. This remains true as of when this article was completed in November 2007. George W. Downs, David M. Rocke \& Peter N. Barsoom, "Is the good news about compliance good news about cooperation?” (1996) 50 International Organization 379.

140 Karen Alter, “Do International Courts Enhance Compliance with International Law?” (2003) 25 Review of Asian \& Pacific Studies 51.

${ }_{141}$ For a discussion, see Jeffrey L. Dunoff, "Reconciling International Trade with Preservation of the Global Commons: Can We Prosper and Protect?” (1992) 49 Wash. \& Lee L. Rev. 1407. 
production patterns, whether the market access provisions in trade agreements override domestic environmental regulations, and whether trade measures can be used as leverage in multilateral environmental efforts.

In the labour context, much of the debate revolves around competitiveness issues. Some argue that goods produced under dismal working conditions constitute a form of "unfair" competition. ${ }^{142}$ Moreover, critics argue that given capital mobility, divergent labour standards might produce a "race to the bottom," with firms moving to take advantage of favourable labour rates and high-standard states facing pressures to lower their labour standards. Critics fear that the threat of capital flight can depress wages in developed states, while actual capital movements produce unemployment. ${ }^{143}$ Similar arguments arise in the related fields of human rights and child labour.

One issue common to of these "fair trade" concerns is whether questions of "fair" labour standards, human rights, environmental protection, and other politically sensitive issues should be addressed by the trade regime or should be addressed in different fora. ${ }^{144}$ Many non-governmental organizations and activists, particularly in the U.S. and Western Europe, believe that these matters should be incorporated into trade agreements, and that trade liberalization should be subordinated to various social objectives. On the other hand, many business leaders and government officials, particularly in developing states, strongly oppose the integration of these issues into the trade regime, fearing that labour, human rights, environment, and similar issues can easily be used for protectionist purposes.

Much of this debate presupposes that it is possible to isolate and "decompose” individual international regimes, such as the human rights or trade regimes. ${ }^{145}$ But the increasing density of and interactions among international regimes make such decomposition infeasible. The complex links among regimes mean that the international system increasingly consists of a rich set of overlapping regimes, nested regimes, and regime complexes, or "an array of partially overlapping institutions governing a particular issue area, among which there is no agreed hierarchy." ${ }^{146}$ The reality of overlapping and nested regimes problematizes the debate

142 For more on the links between trade and labor issues, see Andrew T.F. Lang, "Re-thinking Trade and Human Rights” (2007) 15 Tulane J. Int’l \& Comp L. 335; Michael J. Trebilcock \& Robert Howse, “Trade Policy and Labor Standards” (2005) 14 Minn. J. Global Trade 261.

Daniel C. Esty \& Damien Geradin, eds., Regulatory Competition and Economic Integration: Comparative Perspectives (Oxford: Oxford University Press, 2001).

144 For a sampling of the debate, see Andrew T. Guzman, “Global Governance and the WTO” (2004) 45 Harv. Int’l L. J. 303; John O. McGinnis \& Mark L. Movsesian, “Against Global Governance in the WTO” (2004) 45 Harv. Int'l L. J. 353; Jeffrey L. Dunoff, “Institutional Misfits: The GATT, the ICJ \& Trade-Environment Disputes” (1994) 15 Mich. J. Int’l L. 1043.

For more on decomposable international regimes, see Robert O. Keohane \& Joseph S. Nye, Jr., "The Club Model of Multilateral Cooperation and Problems of Democratic Legitimacy” in Roger B. Porter et al., eds., Efficiency, Equity and Legitimacy: The Multilateral Trading System at the Millennium (Washington, D.C.: Brookings Institution Press, 2001) 264.

146 On regime complexes, see Kal Raustiala \& David G. Victor, “The Regime Complex for Plant Genetic Resources” (2004) 58 International Organization 277; Laurence R. Helfer, "Regime Shifting: The TRIPS Agreement and New Dynamics of International Intellectual Property Lawmaking” (2004) 29 Yale J. Int'l L. 1; Vinod K. Aggarwal, ed., Institutional Designs for a Complex World: Bargaining, Linkages and Nesting (Ithaca, N.Y.: Cornell University Press, 1998); Karen J. Alter \& Sophie Meunier, "Nested and overlapping regimes in the transatlantic banana trade dispute" (2006) 13 Journal of European Public Policy 362. 
over whether, for example, fair labour issues should be addressed at the WTO or the ILO. The increasingly dense network of international institutions and norms renders such a starkly dichotomous choice illusory. In fact, cross-cutting issues, including "fair" trade issues, are invariably addressed in multiple fora.

Moreover, much of the debate over "fair" trade presupposes areas of irreconcilable doctrinal conflict between trade rules and rules from other areas of international law, such as environment or human rights. To be sure, serious tensions sometimes exist between the values that underlie different international regimes. However, the thesis set out above - that the challenges facing the trade system are instantiations of larger challenges facing the international legal order — suggests another perspective.

From this alternative perspective, instead of seeing tension and differences among the various regimes, we might see similarities in the structural challenges that each regime faces. This perspective suggests that, instead of viewing the international legal order as a horizontal world of co-equal and conflicting international regimes, various international regimes might instead visualized as something akin to a set of Russian matryoshka dolls. In this vision, larger and smaller international legal regimes have similar contours, and face similar challenges, including doctrinal coherence, tribunal proliferation, and pervasive risks of noncompliance. This perspective also suggests that the international lawyers who specialize in these regimes may, inadvertently, be engaged in parallel projects.

\section{ConCLuSION}

The Softwood Lumber dispute is, if not misunderstood, at least underappreciated. To date, the dispute has attracted attention because of the substantial economic interests involved, the complexity and length of the legal proceedings, and the doctrinal implications of the various decisions rendered in this long-running dispute. However, the central importance of the Softwood Lumber dispute lies elsewhere. Indeed, for trade scholars, the dispute is important because it exposes three of the central challenges facing the international trade regime: the potential displacement of an international regime by a spaghetti bowl of regional and bilateral treaties; the status of international trade norms in domestic courts; and the problem of noncompliance by powerful states. These challenges, in turn, are instantiations of three central challenges facing the field of public international law, namely the fragmentation of international law, the relationships among proliferating transnational courts, and the limits of (international) legalization. In short, the many dimensions of the dispute highlight many of the dilemmas facing the current trade law and international law systems. Perhaps more importantly, the dispute can help us to rethink at least some of these dilemmas. This is why, despite its tortuous history and arcane doctrine, the many dimensions of the Softwood Lumber dispute deserve our sustained attention. 